\title{
Phytoplankton responses and associated carbon cycling during shipboard carbonate chemistry manipulation experiments conducted around Northwest European shelf seas
}

\author{
S. Richier ${ }^{1}$, E. P. Achterberg ${ }^{1,2}$, C. Dumousseaud ${ }^{1}$, A. J. Poulton ${ }^{3}$, D. J. Suggett ${ }^{4,5}$, T. Tyrrell ${ }^{1}$, M. V. Zubkov ${ }^{3}$, and \\ C. M. Moore ${ }^{1}$ \\ ${ }^{1}$ Ocean and Earth Science, National Oceanography Centre Southampton, University of Southampton, \\ Southampton, UK \\ ${ }^{2}$ GEOMAR Helmholtz Centre for Ocean Research, 24148 Kiel, Germany \\ ${ }^{3}$ National Oceanography Centre of Southampton Waterfront Campus, Southampton, UK \\ ${ }^{4}$ University of Essex, Essex, UK \\ ${ }^{5}$ Climate Change Cluster (C3), University of Technology, Sydney, P.O. Box 123 Broadway, NSW 2007, Australia
}

Correspondence to: S. Richier (s.richier@noc.soton.ac.uk)

Received: 22 January 2014 - Published in Biogeosciences Discuss.: 3 March 2014

Revised: 4 July 2014 - Accepted: 1 August 2014 - Published: 9 September 2014

\begin{abstract}
The ongoing oceanic uptake of anthropogenic carbon dioxide $\left(\mathrm{CO}_{2}\right)$ is significantly altering the carbonate chemistry of seawater, a phenomenon referred to as ocean acidification. Experimental manipulations have been increasingly used to gauge how continued ocean acidification will potentially impact marine ecosystems and their associated biogeochemical cycles in the future; however, results amongst studies, particularly when performed on natural communities, are highly variable, which may reflect community/environment-specific responses or inconsistencies in experimental approach. To investigate the potential for identification of more generic responses and greater experimentally reproducibility, we devised and implemented a series $(n=8)$ of short-term (2-4 days) multi-level ( $\geq 4$ conditions) carbonate chemistry/nutrient manipulation experiments on a range of natural microbial communities sampled in Northwest European shelf seas. Carbonate chemistry manipulations and resulting biological responses were found to be highly reproducible within individual experiments and to a lesser extent between geographically separated experiments. Statistically robust reproducible physiological responses of phytoplankton to increasing $p \mathrm{CO}_{2}$, characterised by a suppression of net growth for small-sized cells $(<10 \mu \mathrm{m})$, were observed in the majority of the experiments, irrespective of natural or manipulated nutrient
\end{abstract}

status. Remaining between-experiment variability was potentially linked to initial community structure and/or other site-specific environmental factors. Analysis of carbon cycling within the experiments revealed the expected increased sensitivity of carbonate chemistry to biological processes at higher $p \mathrm{CO}_{2}$ and hence lower buffer capacity. The results thus emphasise how biogeochemical feedbacks may be altered in the future ocean.

\section{Introduction}

Since the beginning of the industrial period, the oceans have taken up around $25-33 \%$ of anthropogenic $\mathrm{CO}_{2}$ emissions (Ciais et al., 2013). This additional carbon increases the dissolved inorganic carbon $\left(C_{\mathrm{T}}\right)$ pool and causes changes in carbonate chemistry including an increase in proton concentration $\left(\left[\mathrm{H}^{+}\right]\right)$(lowering of $\mathrm{pH}$ ) in surface waters, which is widely termed "ocean acidification" (Caldeira and Wickett, 2003; The Royal Society, 2005). Such changes in carbonate chemistry have the potential to influence a range of biological processes (Riebesell and Tortell, 2011). For example, drops in $\mathrm{pH}$ and carbonate saturation state (i.e. when $\Omega<1$ ) may influence calcification (Orr et al., 2005), while photoautotrophic organisms are also potentially sensitive to increased 
availability of certain inorganic carbon species (Rost et al., 2008; Raven et al., 2011).

Experimental studies investigating the potential impact of ocean acidification on natural phytoplankton communities have generated ambiguous results, often failing to establish generic responses for key organisms or groups, or across communities. For example, primary production measured by ${ }^{14} \mathrm{C}$ fixation or the net production of particulate organic carbon (POC) has variously been shown to be enhanced (Riebesell et al., 2007; Egge et al., 2009; Engel et al., 2013; Silyakova et al., 2013; Eggers et al., 2014), decreased (Riebesell et al., 2009; Zondervan, 2007; Yoshimura et al., 2013), or not significantly influenced (Tortell et al., 2002; Delille et al., 2005; Yoshimura et al., 2013) following experimental elevation of $p \mathrm{CO}_{2}$. Similarly, significant responses to elevated $p \mathrm{CO}_{2}$ have been described for varying groups, including both large-celled diatoms (Feng et al., 2009; Eggers et al., 2014) and pico-/nanoeukaryotes (Brussaard et al., 2013). Observed variability in community-level responses may subsequently be related to differences in experimental design; the influence of other environmental factors; or differential sensitivities amongst species, which may ultimately lead to results being sensitive to the natural composition of microbial communities (Eggers et al., 2014). For example, with respect to $C_{\mathrm{T}}$ uptake and utilisation by phytoplankton, while the majority of taxa are able to regulate their carbon acquisition through use of carbon concentrating mechanisms (CCMs) (Raven and Johnston, 1991), both the efficiency, on reliance on, of and reliance on CCMs likely differs widely among species, between functional groups (Giordano et al., 2005) and as a function of cell size (Wu et al., 2014).

All microbes regulate cellular acid-base balance in the presence of both active solute transports across cellular membranes and primary metabolisms (Raven, 1970; Smith and Raven, 1979; Raven et al., 2011). For phytoplankton in particular, diel variations in the balance between photosynthesis and respiration have the potential to drive large oscillations in proximal cell surface $\left[\mathrm{H}^{+}\right]\left(\left[\mathrm{H}^{+}\right]^{\text {prox }}\right)$ and $p \mathrm{CO}_{2}$ (Flynn et al., 2012) with subsequent cumulative influences on the concentrations of carbonate chemistry species in bulk seawater, e.g. $\left[\mathrm{H}^{+}\right]^{\text {bulk }}$. However, changes in both $\left[\mathrm{H}^{+}\right]^{\text {prox }}$ and $\left[\mathrm{H}^{+}\right]^{\text {bulk }}$ are buffered by the carbonate system (Egleston et al., 2010; Flynn et al., 2012). As the uptake of anthropogenic carbon by the oceans continues into the future, the ability for the carbonate system to resist changes in composition, referred to as buffer capacity, will decline (Egleston et al., 2010). Consequently, microbial processes will tend to drive larger-magnitude diurnal through seasonal-scale variability in both $\left[\mathrm{H}^{+}\right]^{\text {prox }}$ and $\left[\mathrm{H}^{+}\right]^{\text {bulk }}$ (Egleston et al., 2010; Flynn et al., 2012). While all microbes might thus be expected to experience larger ranges in the concentrations of carbonate chemistry species, both relative and absolute changes should vary with cell size, with larger cells having a bigger diffusive boundary layer, expected to experience greater variabil- ity under both natural and altered conditions (Milligan, 2012; Flynn et al., 2012).

The majority of studies aimed at evaluating the effect of ocean acidification on phytoplankton has been performed on individual species (Gattuso and Hansson, 2011), based on single clones isolated from the field many years or decades earlier. Observed physiological responses in such experiments may not be fully representative of populations or natural communities, as a range of complex biological and environmental interactions may be absent (Riebesell and Tortell, 2011). Moreover, cell lines kept in culture may not even have retained the physiological characteristics of the original clones (Joint et al., 2011). Natural community perturbation experiments have the potential to provide a greater environmental relevance through investigation of the entire (microbial) ecosystem structure and function in an environment better approximating natural conditions (Tortell et al., 2002; Delille et al., 2005; Engel et al., 2005; Hare et al., 2007; Feng et al., 2009; Hopkinson et al., 2010; Lomas et al., 2012; Losh et al., 2012). However, interpreting the results of such field experiments can be complicated by the multiple biogeochemical feedbacks and food web interactions, which characterise responses to perturbation in any complex natural community (Rose et al., 2009; Krause et al., 2012; Brussaard et al., 2013). Furthermore, whilst laboratory experiments provide the opportunity for a high degree of replication and thus considerable statistical power, field approaches may have limited scope for replication, with geographical scales often reduced to one unique location (Table 1).

Timescale is also a concern in the interpretation of all ocean acidification research. The temporal scales applied in all field experiments to date (Table 1) are many orders of magnitude smaller than those which will characterise the ocean acidification process driven by slow uptake of anthropogenic $\mathrm{CO}_{2}$ over many decades. The ocean acidification timescale will be comparable to many thousands of microbial generations, suggesting that evolutionary processes are highly likely to have an influence on system-level responses (Collins and Bell, 2006; Lohbeck et al., 2012; Jin et al., 2013; Reusch and Boyd, 2013). Indeed, culture studies performed to date over longer timescales indicate the potential influence of evolutionary adaptation to increased $p \mathrm{CO}_{2}$ over modest $(<1.5 \mathrm{yr}$ ) periods (Lohbeck et al., 2012; Jin et al., 2013). Consequently, although experimentation on natural communities can potentially account for compositional changes, which are highly likely due to both interspecific and intraspecific variations in the plasticity of response (Schaum et al., 2013), they will struggle to account for adaptation occurring through decades of evolutionary processes.

The available experimental techniques for studying ocean acidification could thus all be considered imperfect (Havenhand et al., 2010) and extrapolation of results needs to be performed with great caution. Identification and mechanistic understanding of the ecophysiological sensitivities of differing microbial groups to changes in carbonate chemistry 
Table 1. Environmental relevance versus experimental power. For each approach, an example of the study involving the longest incubation period is listed.

\begin{tabular}{|c|c|c|c|c|c|c|c|c|}
\hline Approach & $\begin{array}{l}\text { Experimental } \\
\text { subjects }\end{array}$ & $\begin{array}{l}\text { Time- } \\
\text { scale }\end{array}$ & $\begin{array}{l}\text { Modification of } \\
\text { initial conditions }\end{array}$ & $\begin{array}{l}\text { Number of } \\
\text { generations }\end{array}$ & $\begin{array}{l}\text { Geographic } \\
\text { scale }\end{array}$ & Processes & Replicates & References \\
\hline Lab - culture & Monospecies & $470 \mathrm{~d}$ & Aquil media & 682 & - & Adaptation & 3 & Jin et al. (2013) \\
\hline \multirow[t]{3}{*}{ In situ } & $\begin{array}{l}\text { Communities } \\
\text { (microcosm) }\end{array}$ & $30 \mathrm{~d}$ & $\begin{array}{l}200 \mu \mathrm{m} \text { filtered, } \\
0.2 \mu \mathrm{m} \text { seawater } \\
\text { dilution }\end{array}$ & $\approx 7-40^{*}$ & 1 site & Acclimation & 3 & Hoppe et al. (2013) \\
\hline & $\begin{array}{l}\text { Communities } \\
\text { (bioassay) }\end{array}$ & $4 d$ & in situ condition & $1-2^{* *}$ & 8 sites & Acclimation & $3-9$ & this study \\
\hline & $\begin{array}{l}\text { Ecosystems } \\
\text { (observations) }\end{array}$ & $>10 \mathrm{yr}$ & - & $>2000$ & Global & $\begin{array}{l}\text { Acclimation/ } \\
\text { adaptation }\end{array}$ & & \\
\hline
\end{tabular}

Notes: ${ }^{*}$ Spies et al. (1987); ${ }^{* *}$ calculated on the basis of maximum observed net growth rates and hence likely lower bound for actual number of generations.

Table 2. Starting conditions in the bioassay experiments. Data for salinity and temperature (Temp.) were determined in situ using the CTD. Average ( \pm standard deviation) values are given when available. The total depth of the water column at the sampling sites is indicated after sampling depth in square brackets.

\begin{tabular}{|c|c|c|c|c|c|c|c|c|c|c|c|}
\hline Exp. & $\begin{array}{l}\text { Lat. } \\
\left({ }^{\circ} \mathrm{N}\right)\end{array}$ & $\begin{array}{l}\text { Long. } \\
\left({ }^{\circ} \mathrm{W} / \mathrm{E}\right)\end{array}$ & $\begin{array}{c}C_{\mathrm{T}} \\
\left(\mu \mathrm{mol} \mathrm{kg}{ }^{-1}\right)\end{array}$ & $\begin{array}{c}A_{\mathrm{T}} \\
\left(\mu \mathrm{mol} \mathrm{kg}{ }^{-1}\right)\end{array}$ & $\begin{array}{l}\text { Temp. } \\
\left({ }^{\circ} \mathrm{C}\right)\end{array}$ & Salinity & $\begin{array}{l}\text { Depth } \\
\text { (m) }\end{array}$ & $\left.\begin{array}{c}\mathrm{NO}_{3}^{-} \\
(\mu \mathrm{mol} \mathrm{L} \\
-1\end{array}\right)$ & $\left.\begin{array}{c}\mathrm{PO}_{4}^{3-} \\
(\mu \mathrm{mol} \mathrm{L} \\
-1\end{array}\right)$ & $\left.\begin{array}{c}\mathrm{dSi} \\
(\mu \mathrm{mol} \mathrm{L} \\
-1\end{array}\right)$ & $\begin{array}{c}\text { Chl } a \\
\left(\mu \mathrm{g} \mathrm{L}^{-1}\right)\end{array}$ \\
\hline 1 & 56.79 & -7.42 & $2091.8(0.9)$ & $2310.9(2.3)$ & 11.27 & 34.80 & 6 [180] & $1.06(0.1)$ & $0.09(0.0)$ & $2.07(0.2)$ & $3.22(0.0)$ \\
\hline $2 b$ & 46.50 & -7.22 & 2085.8 & 2345.6 & 15.02 & 35.67 & $5[4600]$ & $0.94(0.1)$ & $0.07(0.0)$ & $1.15(0.0)$ & $0.55(0.0)$ \\
\hline 3 & 46.20 & -7.22 & $2083.8(0.6)$ & $2347.1(3.6)$ & 15.31 & 35.77 & $10[200]$ & $0.56(0.0)$ & $0.06(0.0)$ & $0.61(0.0)$ & $0.77(0.0)$ \\
\hline 4 & 53.00 & 2.5 & $2085.5(1.6)$ & $2295.6(0.4)$ & 14.57 & 34.05 & $5[30]$ & $0.87(0.1)$ & $0.12(0.0)$ & $0.8(0.0)$ & $1.32(0.0)$ \\
\hline $5 b$ & 59.68 & 4.12 & 1997.2 & 2214.1 & 13.30 & 30.50 & $4[270]$ & $0.26(0.0)$ & 0.0 & 0.0 & $0.8(0.0)$ \\
\hline
\end{tabular}

is thus crucial. In the current study we prioritised experimental replication and hence greater geographical and environmental coverage of the responses of natural upper-ocean microbial communities to carbonate chemistry manipulation. Specifically, we designed and implemented a series of shipboard experiments focusing on the short-timescale responses of multiple variables to imposed discrete changes in $p \mathrm{CO}_{2}$ and other associated carbonate chemistry species.

The impact of experimentally imposed shifts in carbonate chemistry on phytoplankton processes and subsequent carbon cycling, including inorganic uptake and organic matter release, was investigated in Northwest European shelf seas within a series of experiments performed at five $p \mathrm{CO}_{2}$ levels, alongside three additional experiments where both macronutrients and carbonate chemistry were simultaneously manipulated. Within the current manuscript, we describe the overall implementation of the experiments with reference to current advice on best practice in ocean acidification research (Barry et al., 2010; Havenhand et al., 2010; LaRoche et al., 2010) and present some first-order biogeochemical responses.

\section{Methods}

\subsection{Bioassay setup}

Shipboard incubation experiments were conducted onboard the RRS Discovery as part of cruise D366 (6 June-10 July 2011). Experimental locations are indicated in Fig. 1 and presented in Table 2, alongside the initial environmental conditions for each of the eight bioassay experiments performed: five multi- $p \mathrm{CO}_{2}$-level manipulation experiments (E1-E5, hereafter termed main experiments) and three combined carbonate chemistry/macronutrient manipulation experiments (E2b, E4b and E5b, hereafter termed additional experiments). On the day of the experimental setup, vertical profiles of temperature, salinity, oxygen, fluorescence, turbidity and irradiance were obtained in order to choose and characterise the depth of experimental water collection within the water column structure. Vertical profiles of temperature and chlorophyll fluorescence from the main experiments are presented in Fig. 2. Experiments were set up and run in three principal stages as detailed below. 
Table 3. Biological and chemical variables measured in each of the main bioassay experiments (Richier et al., 2014).

\begin{tabular}{|c|c|c|}
\hline Category & Parameter measured & References \\
\hline Carbonate chemistry & $\begin{array}{l}C_{\mathrm{T}}\left(\mu \mathrm{mol} \mathrm{kg} \mathrm{kg}^{-1}\right) \\
A_{\mathrm{T}}\left(\mu \mathrm{mol} \mathrm{kg}{ }^{-1}\right) \\
\mathrm{pH}(\text { total scale })\end{array}$ & $\begin{array}{l}\text { Dickson et al. (2007) } \\
\text { Dickson et al. (2007) } \\
\text { Rerolle et al. (2012) }\end{array}$ \\
\hline Nutrient concentrations & 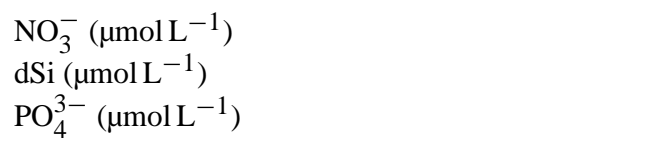 & $\begin{array}{l}\text { Kirkwood (1996) } \\
\text { Kirkwood (1996) } \\
\text { Kirkwood (1996) }\end{array}$ \\
\hline $\begin{array}{l}\text { Standing stock } \\
\text { Composition } \\
\text { Phytoplankton physiology }\end{array}$ & $\begin{array}{l}\text { Total Chl } a\left(\mathrm{mg} \mathrm{m}^{-3}\right) \\
>10 \mu \mathrm{m} \mathrm{Chl} a\left(\mathrm{mg} \mathrm{m}^{-3}\right) \\
F_{\mathrm{V}} / F_{\mathrm{m}} \\
\text { sigma } \\
\tau\end{array}$ & $\begin{array}{l}\text { Welschmeyer (1994) } \\
\text { Welschmeyer (1994) } \\
\text { Moore et al. (2006) } \\
\text { Moore et al. (2006) } \\
\text { Moore et al. (2006) }\end{array}$ \\
\hline Biological processes & $\begin{array}{l}\text { Primary Production }\left(\mathrm{mmol} \mathrm{C} \mathrm{m}^{-3} \mathrm{~d}^{-1}\right) \\
\text { Calcite production }\left(\mu \mathrm{mol} \mathrm{C} \mathrm{m} \mathrm{m}^{-3} \mathrm{~d}^{-1}\right) \\
>10 \mu \mathrm{m} \text { Primary production }\left(\mathrm{mmol} \mathrm{C} \mathrm{m}^{-3} \mathrm{~d}^{-1}\right)\end{array}$ & $\begin{array}{l}\text { Poulton et al. }(2010,2014) \\
\text { Poulton et al. }(2010,2014) \\
\text { Poulton et al. }(2010,2014)\end{array}$ \\
\hline Biogenic material & $\begin{array}{l}\text { Bsi }\left(\mu \mathrm{mol} \mathrm{Si} \mathrm{L}{ }^{-1}\right) \\
\text { PIC }\left(\mu \mathrm{mol} \mathrm{C} \mathrm{L}{ }^{-1}\right)\end{array}$ & $\begin{array}{l}\text { Poulton et al. (2006) } \\
\text { Poulton et al. (2006) }\end{array}$ \\
\hline Organic matters & $\begin{array}{l}\text { POP }\left(\mu \mathrm{mol} \mathrm{L}{ }^{-1}\right) \\
\text { POC }(\mu \mathrm{mol} \mathrm{L}-1) \\
\text { PON }\left(\mu \mathrm{mol} \mathrm{L}{ }^{-1}\right) \\
\text { DOC }(\mu \mathrm{mol} \mathrm{L}-1) \\
\text { DON }\left(\mu \mathrm{mol} \mathrm{L}^{-1}\right)\end{array}$ & $\begin{array}{l}\text { Raimbault et al. (1999) } \\
\text { Verardo et al. (1990) } \\
\text { Verardo et al. (1990) } \\
\text { Spyres et al. (2000) } \\
\text { Badr et al. (2003) }\end{array}$ \\
\hline Community structure & $\begin{array}{l}\text { Coccolithophores }\left(\text { cell } \mathrm{mL}^{-1}\right) \\
\left.\text { LNA bacteria (cell } \mathrm{mL}^{-1}\right) \\
\left.\text { HNA bacteria (cell } \mathrm{mL}^{-1}\right) \\
\text { Total bacteria }\left(\text { cell } \mathrm{mL}^{-1}\right) \\
\left.\text { Synechococcus (cell } \mathrm{mL}^{-1}\right) \\
\left.\text { Heterotrophic nanoflagellates (cell } \mathrm{mL}^{-1}\right) \\
\text { Phototrophic nano- and picoplankton }\left(\text { cell } \mathrm{mL}^{-1} \text { ) }\right. \\
\text { Diatoms, ciliates, dinoflagellates }\left(\text { cell } \mathrm{mL}^{-1}\right)\end{array}$ & $\begin{array}{l}\text { Poulton et al. (2010) } \\
\text { Marie et al. (1997) } \\
\text { Marie et al. (1997) } \\
\text { Marie et al. (1997) } \\
\text { Zubkov et al. (2007) } \\
\text { Zubkov et al. (2007) } \\
\text { Zubkov et al. (2007) } \\
\text { Poulton et al. (2010) }\end{array}$ \\
\hline Nitrogen cycle & $\begin{array}{l}\mathrm{NH}_{4}\left(\mathrm{nmol} \mathrm{L}^{-1}\right) \\
\mathrm{NH}_{4 \mathrm{reg}}\left(\mathrm{nmol} \mathrm{L}^{-1} \mathrm{~h}^{-1}\right) \\
\mathrm{NH}_{4 \mathrm{ox}}\left(\mathrm{nmol} \mathrm{L}^{-1} \mathrm{~h}^{-1}\right) \\
\mathrm{N}_{2} \mathrm{O}\left(\mathrm{nmol} \mathrm{L}^{-1}\right)\end{array}$ & $\begin{array}{l}\text { Clark et al. }(2007,2014) \\
\text { Clark et al. }(2007,2014) \\
\text { Clark et al. }(2007,2014) \\
\text { Rees et al. }(2011)\end{array}$ \\
\hline Others & $\begin{array}{l}\text { TEP }\left(\mu \mathrm{g} . \text { Xeq } \mathrm{L}^{-1}\right) \\
\text { TN }\left(\mu \mathrm{mol} \mathrm{L} \mathrm{L}^{-1}\right) \\
\text { DMS }\left(\mathrm{nmol} \mathrm{L}^{-1}\right) \\
\text { Total DMSP }\left(\mathrm{nmol} \mathrm{L}^{-1}\right) \\
\text { Particulate DMSP }\left(\mathrm{nmol} \mathrm{L}^{-1}\right) \\
\mathrm{CH}_{4}\left(\mathrm{nmol} \mathrm{L}^{-1}\right)\end{array}$ & $\begin{array}{l}\text { Passow and Alldredge (1995) } \\
\text { Hilton et al. (1986) } \\
\text { Archer et al. (2013) } \\
\text { Archer et al. (2013) } \\
\text { Stefels et al. (2009) } \\
\text { Upstill-Goddard (1996) }\end{array}$ \\
\hline
\end{tabular}

\subsubsection{Water collection and filling}

Unfiltered water from within the surface mixed layer $(<20$ $\mathrm{m})$ containing the intact natural community was collected from a dedicated CTD cast. Once on deck, the total seawater collected within the $24 \times 20$ L CTD Rosette OTE (Ocean Test Equipment) bottles (480 L) was dispensed from randomly assigned OTE bottles through silicon tubing amongst $72 \times 4.5 \mathrm{~L}(\mathrm{E} 1-\mathrm{E} 5)$ or $24 \times 1.25 \mathrm{~L}$ (E2b, E4b and E5b) acid- washed and Milli-Q rinsed clean clear polycarbonate bottles $\left(\right.$ Nalgene $\left.^{\mathrm{TM}}\right)$ which were filled without headspace. Subsamples were collected simultaneously for time-zero $\left(T_{0}\right)$ measurements of each of the variables to be measured over the subsequent time course (Table 3). 


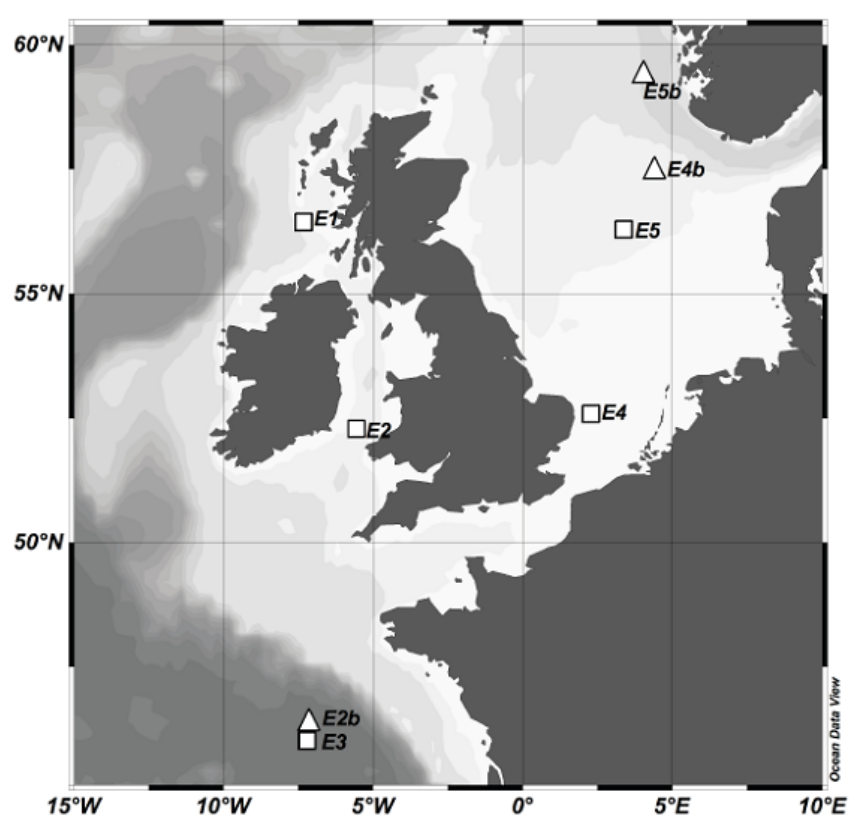

Figure 1. Locations of the main (E1-E5) (square) and the additional (E2b, E4b and E5b) (triangle) bioassay experiments performed during D366 cruise around NW European continental shelf seas.

\subsubsection{Carbonate chemistry manipulation and nutrient additions}

Subsamples at time zero $\left(T_{0}\right)$, taken directly from the CTD, were immediately measured for total alkalinity $\left(A_{\mathrm{T}}\right)$ and dissolved inorganic carbon (Table 2) and hence characterisation of the carbonate chemistry system in seawater. Dissolved inorganic carbon was analysed with an Apollo SciTech $C_{\mathrm{T}}$ analyser (AS-C3), which uses a $\mathrm{CO}_{2}$ infrared detector (LICOR 7000). Total alkalinity was determined using a semiclosed-cell titration (Dickson et al., 2007) within the Apollo SciTech's AS-ALK2 Alkalinity Titrator. For both $C_{\mathrm{T}}$ and $A_{\mathrm{T}}$ the precision was $0.1 \%$ or better, with accuracy verified using certified reference materials (A.G. Dickson, Scripps). The remaining variables of the carbonate system were calculated with the CO2SYS programme (version 1.05, Lewis and Wallace, 1998; Pierrot et al., 2006), using the constants of Mehrbach et al. (1973) refitted by Dickson and Millero (1987). Carbonate chemistry in the experimental bottles was subsequently manipulated using equimolar additions of strong acid $\left(\mathrm{HCl}, 1 \mathrm{~mol} \mathrm{~L}^{-1}\right)$ and $\mathrm{HCO}_{3}^{-}\left(1 \mathrm{~mol} \mathrm{~L}^{-1}\right)$. This approach constitutes one of three methods allowing accurate replication of ongoing and future changes in seawater carbonate chemistry, namely an increase in $C_{\mathrm{T}}$ at constant $A_{\mathrm{T}}$ (Gattuso et al., 2010). The volumes of $\mathrm{HCl}$ and $\mathrm{HCO}_{3}^{-}$ required to adjust $p \mathrm{CO}_{2}$ to the chosen target values (ambient, 550, 750 and $1000 \mu \mathrm{atm}$ ) were calculated from the measured ambient state of the carbonate system in seawater using CO2SYS. In order to validate the carbonate chemistry manipulation, four additional bottles were adjusted to the exper- imental conditions and immediately subsampled and measured as manipulated $T_{0}$ values.

Additional experiments were supplemented with low levels of major macronutrients (nitrate $\left(\mathrm{NO}_{3}^{-}\right)$, silicic acid $(\mathrm{dSi})$ and phosphate $\left(\mathrm{PO}_{3}^{-}\right)$) under the ambient state of the carbonate system or manipulated towards a target $p \mathrm{CO}_{2}$ of $750 \mu \mathrm{atm}$. Four nutrient conditions were run in triplicate: (1) control, (2) $2 \mu \mathrm{mol} \mathrm{L}-1$ added $\mathrm{NO}_{3}^{-}$and $\mathrm{dSi}$, (3) $0.2 \mu \mathrm{mol} \mathrm{L}-1$ added $\mathrm{PO}_{3}^{-}$and $2 \mu \mathrm{mol} \mathrm{L}{ }^{-1} \mathrm{dSi}$ and (4) $2 \mu \mathrm{mol} \mathrm{L}{ }^{-1}$ added $\mathrm{NO}_{3}^{-}$and $\mathrm{dSi}$ and $0.2 \mu \mathrm{mol} \mathrm{L}{ }^{-1}$ added $\mathrm{PO}_{3}^{-}$(hereafter control, $+\mathrm{N},+\mathrm{P},+\mathrm{NP}$ ), with four independent bottles analysed for $T_{0}$ values.

\subsubsection{Incubation}

Microbial communities were incubated in a purposely converted commercial refrigeration container located on the aft deck of the ship. Irradiance $\left(100 \mu \mathrm{mol}\right.$ photons $\left.\mathrm{m}^{-2} \mathrm{~s}^{-1}\right)$ was provided by daylight simulation LED panels (Powerpax, UK) over a $18-6 \mathrm{~h}$ light-dark cycle approximating the ambient photoperiod. The integrated daily light dose in the experiments $\left(6.5 \mathrm{~mol}\right.$ photons $\left.\mathrm{m}^{-2} \mathrm{~d}^{-1}\right)$ was chosen to be broadly comparable to the estimated integrated light dose experienced by the phytoplankton populations in situ within the mixed layer, which ranged from 3 to $17 \mathrm{~mol}$ photons $\mathrm{m}^{-2}$ $\mathrm{d}^{-1}$ (Poulton et al., 2014; this issue). Temperature was maintained at the in situ values $\left( \pm<1^{\circ} \mathrm{C}\right)$ at the time of water collection (Table 2). For the five main experiments (E1-E5), incubations lasted for a total of 4 days $(96 \mathrm{~h})$, including a time point after 2 days ( $48 \mathrm{~h}$ ), with separate incubation bottles being sacrificed at every sampling point. The additional experiments including inorganic nutrient addition (E2b, E4b and E5b) were run under the same temperature and light regime for a shorter incubation period of $48 \mathrm{~h}$ with a single sampling point at the end.

\subsection{Measured variables}

In order to provide the volume of water required for the measurement of the whole suite of sampled variables in the main experiments (Table 3), it was necessary to incubate a total of 18 bottles for each of the four conditions tested (ambient, 550,750 and $1000 \mu \mathrm{atm}$ ), half of which were sacrificially sampled at each of the two sampling points (48 and $96 \mathrm{~h}$ ). For each time point and treatment, the replicate set of nine bottles were further split into three sets of triplicate bottles hereafter referred to as "Group A, B and C". A range of variables with low volume requirements (total chlorophyll $a(\mathrm{Chl}$ a), macronutrients, carbonate chemistry variables and community structure as measured by flow cytometry) were sampled across all three sets (i.e. nine replicates), providing a check on reproducibility between the groups of triplicates, and a further measure of biological reproducibility within the whole experimental process. The rest of the variables, requiring larger volume, were only sampled out of one set of 
triplicate bottles. Methods for variables explicitly discussed herein are briefly described below. References for other methods are provided in Table 3. Due to the limited seawater volume available within the additional experiments, fewer variables were measured in triplicates, specifically, carbonate chemistry $\left(C_{\mathrm{T}}\right.$ and $\left.A_{\mathrm{T}}\right)$, macronutrients, total and sizefractionated Chl $a$, photosynthetic efficiency $\left(F_{\mathrm{v}} / F_{\mathrm{m}}\right.$, FRRf $)$, DMS/DMSP (dimethyl sulfide/dimethylsulfoniopropionate; Hopkins et al., 2014), primary production, calcite production (CP) and coccolithophore cell counts (see Poulton et al., 2014; Young et al., 2014; this issue).

\subsection{Particulate organic carbon (POC)}

Aliquots of $750 \mathrm{~mL}$ of seawater were filtered onto $25 \mathrm{~mm}$ glass fibre filters (Fisher MF 300), pre-combusted at $400^{\circ} \mathrm{C}$ and oven-dried at $60^{\circ} \mathrm{C}$ for $8-12 \mathrm{~h}$. Inorganic carbonates were removed from the filters by acidification with sulphurous acid $[6 \% w / v]$ under vacuum for $24-48 \mathrm{~h}$ (Verardo et al., 1990). The filters were then re-dried at $60^{\circ} \mathrm{C}$ for $24 \mathrm{~h}$, packaged in pre-combusted aluminium foil (Hilton et al., 1986) and analysed on a Thermo Finnigan flash EA1112 elemental analyser using acetanilide as the calibration standard.

\subsection{Nutrients}

Samples for macronutrients (nitrate $\left(\mathrm{NO}_{3}^{-}\right)$, silicic acid (dSi) and phosphate $\left(\mathrm{PO}_{3}^{-}\right)$) were collected directly from each of the incubation bottles into a $25 \mathrm{~mL}$ polystyrene container and stored at $4{ }^{\circ} \mathrm{C}$ pending analysis within $12 \mathrm{~h}$. The samples were run on a Skalar San+Segmented Flow Autoanalyzer using colorimetric techniques (Kirkwood, 1996) with the exception that the flow rate of the sample through the phosphate channel was increased to improve reproducibility and peak shape.

\subsection{Total and size-fractionated Chl $a$ and net growth}

Aliquots of $100 \mathrm{~mL}$ were sampled from incubation bottles and filtered onto $25 \mathrm{~mm} \mathrm{GF} / \mathrm{F}$ filters (Whatman, $0.7 \mu \mathrm{m}$ nominal pore size) or $10 \mu \mathrm{m}$ pore size polycarbonate filters (Whatman) (to yield a total and $>10 \mu \mathrm{m}$ size fraction, respectively and therefore by difference a $<10 \mu \mathrm{m}$ size fraction). Filters were extracted into $6 \mathrm{~mL} 90 \%$ highperformance liquid chromatography (HPLC)-grade acetone overnight at $4{ }^{\circ} \mathrm{C}$ in the dark and fluorescence was then measured using a fluorometer (Turner Designs Trilogy) (Welschmeyer, 1994). Final Chl $a$ concentrations were calibrated against dilutions of a solution of pure Chl $a$ (Sigma, UK) in $90 \%$ acetone with instrument drift further corrected by daily measurement of a solid fluorescence standard. Net growth rates were estimated from changes in Chl $a$ as: $\mu=\left(\ln \left(\mathrm{C}_{1}\right)-\ln \left(\mathrm{C}_{0}\right)\right) \Delta t^{-1}$ where $\mathrm{C}_{0}$ and $\mathrm{C}_{1}$ are the total $\mathrm{Chl} a$ concentrations at the beginning and after $48 \mathrm{~h}$ incuba- tion period, respectively and $\Delta t$ is the duration of incubation in days (Table 1).

\subsection{Variable chlorophyll fluorescence $\left(F_{\mathrm{v}} / \boldsymbol{F}_{\mathrm{m}}\right)$}

The photosynthetic physiology of natural communities was measured using a FastTrackaTM Mk II Fast Repetition Rate fluorometer (FRRf) integrated with a FastActTM Laboratory system (Chelsea Technologies Group LTD, West Molesey, Surrey, UK). All samples were dark acclimated for $30 \mathrm{~min}$ and FRRf measurements were corrected for the blank effect using carefully prepared $0.2 \mu \mathrm{m}$ filtrates for all experiments and time points (Cullen and Davis, 2003). $F_{\mathrm{v}} / F_{\mathrm{m}}$ was taken as an estimate of the apparent photosystem II photochemical quantum efficiency (Kolber et al., 1998).

\subsection{Primary production}

Daily rates (dawn-dawn, $24 \mathrm{~h}$ ) of total primary production (PP) and $>10 \mu \mathrm{m}$ primary production were determined following Poulton et al. (2014) (see also Poulton et al., 2010). Water samples ( $70 \mathrm{~mL}$ volume, three lights) from the incubations were spiked with $15-40 \mu \mathrm{Ci}$ (total PP) or $3-8 \mu \mathrm{Ci}$ (> $10 \mu \mathrm{m} \mathrm{PP})$ of ${ }^{14} \mathrm{C}$-labelled sodium bicarbonate, and incubated for a further $24 \mathrm{~h}$. Incubations were terminated by filtration through $25 \mathrm{~mm} 0.45 \mu \mathrm{m}$ (total) or $25 \mathrm{~mm}$ $10 \mu \mathrm{m}(>10 \mu \mathrm{m})$ polycarbonate filters (NucleporeTM, US). Organic carbon fixation was determined using the MicroDiffusion Technique (MDT) (Poulton et al., 2010, 2014).

\subsection{Community composition}

Phytoplankton community composition was assessed by a combination of flow cytometry (Synechococcus, picoeukaryotes, nanoeukaryotes and heterotrophic nanoflagellates) and inverted light microscopy (microplankton: diatoms, ciliates and dinoflagellates) on water samples collected at the time of experimental water collection. Flow cytometry followed Zubkov et al. (2007) on paraformaldehyde fixed $(0.1 \%$ final concentration) and SYBR Green stained water samples using a Partec CyFlow Space flow cytometer (Partec UK). Cells were identified based on their light-scattering properties, red fluorescence and phycoerythrin fluorescence. Inverted light microscopy followed Poulton et al. (2010) on preserved water samples (2\% final concentration of acidic Lugol's solution) stored in $250 \mathrm{~mL}$ amber glass bottles and enumerated in $50 \mathrm{~mL}$ Hydro-Bios setting chambers on a SP-95-I inverted microscope.

\subsection{Statistical treatment and data archiving}

Statistically significant treatment effects as a function of manipulated carbonate chemistry (target $p \mathrm{CO}_{2}$ ) were evaluated independently for each individual time point within all the individual main experiments using a one-way ANOVA (analysis of variance) followed by a Tukey-Kramer means 


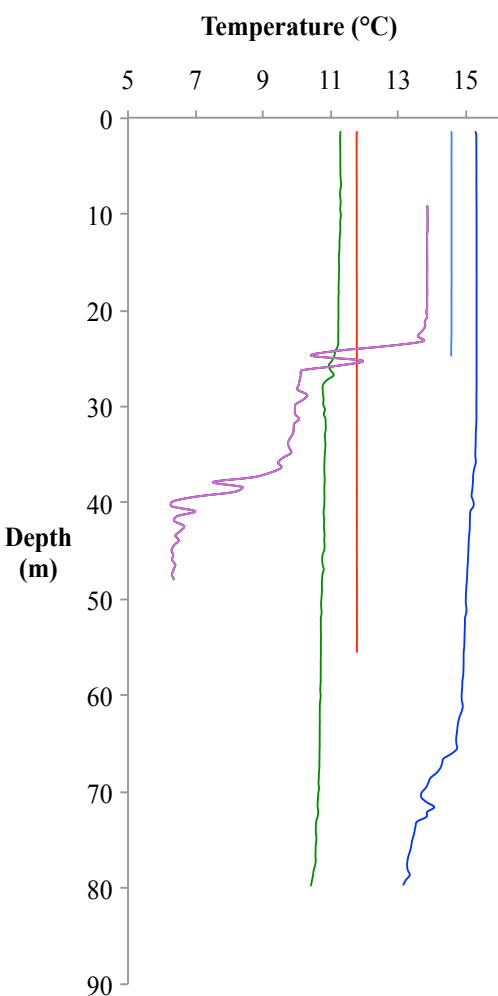

(a)
Chlorophyll fluorescence ( $\mu$ g. $\left.\mathrm{L}^{-1}\right)$

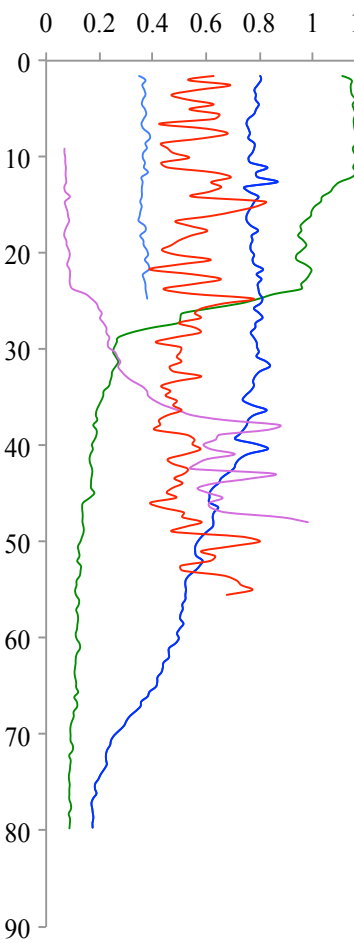

(b)

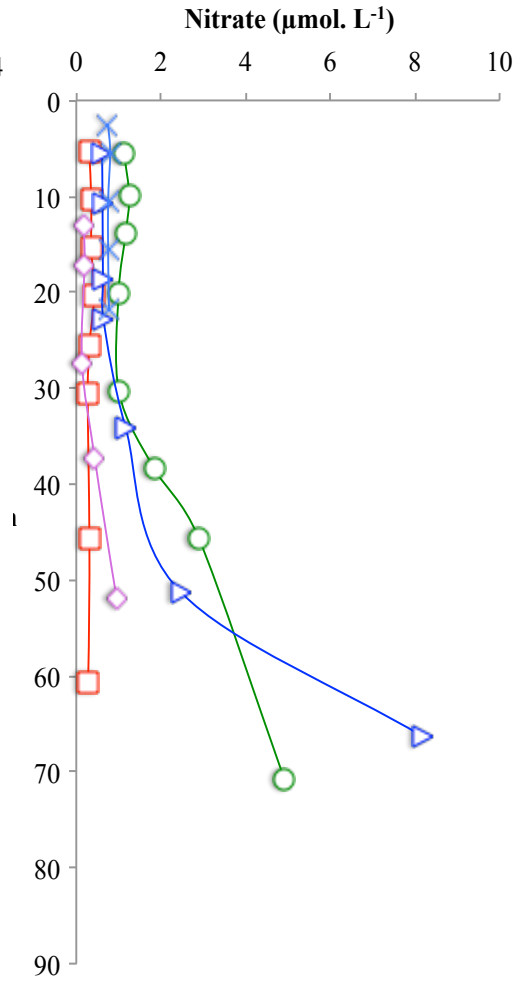

(c)

Figure 2. Vertical profiles of (a) temperature $\left({ }^{\circ} \mathrm{C}\right)$, (b) chlorophyll fluorescence $\left(\mu \mathrm{g} \mathrm{L}{ }^{-1}\right)$ and (c) nitrate $\left(\mu \mathrm{mol} \mathrm{L}^{-1}\right)$ illustrating oceanographic setting of each of the five main bioassay experiments at the time of the setup. Temperature and fluorescence data were obtained from the CTD, and nitrate concentrations from discrete measurements of water column samples. Each colour/symbol corresponds to a bioassay: E1 (green, circles), E2 (red, squares), E3 (dark blue, triangles), E4 (light blue, crosses) and E5 (purple, diamonds).

comparison test. For the combined carbonate-chemistrynutrient-manipulation experiments a two-way ANOVA was used to test for any significant influence of nutrient, target $p \mathrm{CO}_{2}$ or an interaction term between these two manipulated factors. Individual treatments were thus tested for significant differences both with control bottles (ambient $p \mathrm{CO}_{2}$ and nutrients) and all other treatments independently for all experiments. All data included in the paper are available from the British Oceanographic Data Centre (BODC) (Richier et al., 2014).

\section{Results}

\subsection{Oceanographic setting}

The five main bioassay experiments were set up and run along the cruise track at different geographical locations (Fig. 1) characterised by distinct environmental conditions (Table 2). The vertical profiles of temperature, chlorophyll fluorescence and nitrate illustrate the water column characteristics for each of the main experiments at the time of their setup (Fig. 2). Water column conditions ranged from strati- fied (E1, E3 and E5) to fully mixed (E2 and E4). The first experiment (E1) was characterised by high initial concentrations of nitrate $(>1 \mu \mathrm{M})$ and $\mathrm{Chl} a\left(>3 \mu \mathrm{g} \mathrm{L}{ }^{-1}\right)$, while the final (E5) was nutrient depleted $\left(\mathrm{NO}_{3}^{-}<0.2 \mu \mathrm{M}\right) \quad$ with low Chl $a\left(<0.5 \mu \mathrm{g} \mathrm{L}^{-1}\right)$. The water column characteristics at E2 suggested a recent phytoplankton (diatom) bloom with high Chl $a$ and depleted nutrients. Finally, E3 and E4 were set up in warmer waters and show similar initial environmental conditions with intermediate nitrate concentrations (between 0.5 and $1 \mu \mathrm{M}$ ). Initial phytoplankton community compositions, as determined by microscopy and flow cytometry were different between experiments (Table 4). Most phytoplankton communities were dominated by small cells $(>58 \%<10 \mu \mathrm{m} \mathrm{Chl} a$ ), with E2 being the exception ( $20 \%$ $<10 \mu \mathrm{m} \mathrm{Chl} a$ ).

The additional experiments were all set up in locations (Fig. 1) characterised by stratified water columns (results not shown), low surface Chl $a\left(<0.8 \mu \mathrm{g} \mathrm{L}^{-1}\right)$ and intermediate (E2b) to low (E4b and E5b) nutrients (Table 2). Results obtained from size-fractionated $\mathrm{Chl} a$ suggest that the communities in the additional experiments were dominated by small cells $<10 \mu \mathrm{m}$. 
Table 4. Initial plankton community composition for each of the main experiments. Average ( \pm standard deviation) values are given when available.

\begin{tabular}{|c|c|c|c|c|c|c|c|}
\hline \multirow[t]{3}{*}{ Bioassay } & \multirow[t]{2}{*}{$<10 \mu \mathrm{m} \mathrm{Chl} a$} & \multicolumn{4}{|c|}{ Plankton $>10 \mu \mathrm{m}$} & \multicolumn{2}{|c|}{ Plankton $<10 \mu \mathrm{m}$} \\
\hline & & Diatoms & Dinoflagellates & Ciliates & Cryptophytes & $\begin{array}{l}\text { Phototrophic nano- } \\
\text { and picoplankton }\end{array}$ & Synechococcus \\
\hline & {$[\%]$} & & & & {$\left[\right.$ Cells mL $\left.{ }^{-1}\right]$} & & \\
\hline E01 & na & $0.9(0.2)$ & $61.5(23.8)$ & $30.4(47.2)$ & $175.6(264.9)$ & $\mathrm{n} / \mathrm{a}$ & $\mathrm{n} / \mathrm{a}$ \\
\hline E02 & 20 & $44.3(7.8)$ & $39.7(4.8)$ & $1.2(1.21)$ & $5.0(4.5)$ & $1388(85)$ & 4407 (1407) \\
\hline E03 & 58 & $3.2(1.4)$ & $57.2(70.5)$ & $6.3(6.9)$ & $2.6(2.8)$ & $2953(518)$ & $26771(1067)$ \\
\hline E04 & 81 & $2.2(0.5)$ & $41.1(21.4)$ & $1.6(2.1)$ & $38.3(20.6)$ & $6688(3847)$ & 54660 (34 139) \\
\hline E05 & 77 & $2.5(0.2)$ & $20.9(12.4)$ & $7.3(3.3)$ & $6.7(8.0)$ & 6276 (4799) & $149844(8083)$ \\
\hline
\end{tabular}

\subsection{Carbonate chemistry shift and buffer capacity}

The accuracy and precision of the carbonate chemistry manipulations is illustrated in Fig. 3. The achieved $p \mathrm{CO}_{2}$ level was well matched to the target value at $T_{0}$ across all five experiments (Fig. 3a). Decreases in $p \mathrm{CO}_{2}$ were subsequently observed at the 48 and $96 \mathrm{~h}$ time points (Fig. $3 \mathrm{~b}$ and c), which could largely be attributed to biological processes. However, differences in $p \mathrm{CO}_{2}$ between target and measured initial values were more pronounced in the higher- $p \mathrm{CO}_{2}$ treatments, likely reflecting the lower buffer capacity of the carbonate system at higher $p \mathrm{CO}_{2}$ (see below). As expected, total alkalinity remained stable across treatments and throughout the incubation period in the majority of experiments, except in E1, where an unexpected and unexplained difference in $A_{\mathrm{T}}$ values was observed between initial sampling $\left(T_{0}\right)$ and all subsequent time points (Fig. 3d). Consequently we do not consider the detailed carbon cycling within E1 further and treat all results from this experiment with caution. Similar reproducibility and evolution of carbonate chemistry was obtained throughout the $48 \mathrm{~h}$ incubation period in the additional combined $p \mathrm{CO}_{2}$-nutrient manipulation experiments (see Poulton et al., 2014).

\subsection{Experiment reproducibility}

Standard deviations from the biological triplicates differed between the variables sampled, but were typically $<10 \%$ of mean values. Moreover, the biological and chemical variables measured across the three parallel sets of triplicate bottles (groups A, B and C) were highly comparable (Fig. 4). Specifically, carbonate system parameters, which responded to both the imposed environmental forcing and subsequent biological responses and feedbacks, were highly reproducible (Fig. 4a and b) except for data related to $A_{\mathrm{T}}$ for E1, which was more widely spread. In addition to observed consistent absolute magnitudes, observed changes over time in nitrate and total $\mathrm{Chl} a$, representing indices of bulk biological response both to the general enclosure of the community and the different imposed treatments, were also highly reproducible across all experiments (Fig. 4).

\subsection{Carbon cycling and biological processes}

Taken across all the experiments and irrespective of the target $p \mathrm{CO}_{2}$ treatment, net production or remineralisation of POC $(\triangle \mathrm{POC})$ was strongly correlated with net changes in $C_{\mathrm{T}}\left(\Delta C_{\mathrm{T}}\right)(r=0.62, p<0.0001, n=32)$, in a manner, which was largely consistent with the former being the dominant driver of the latter (Fig. 5b, see also Fig. 6a). In contrast, calculated changes in $p \mathrm{CO}_{2}$ and $\mathrm{H}^{+}\left(\Delta p \mathrm{CO}_{2}\right.$ and $\left.\Delta \mathrm{H}^{+}\right)$as a function of $\triangle \mathrm{POC}$ were much more pronounced under higher- $p \mathrm{CO}_{2}$ conditions (Fig. $6 \mathrm{~b}$ and c). Variability in $\triangle p \mathrm{CO}_{2}$ and $\Delta \mathrm{H}^{+}$as a function of $\triangle \mathrm{POC}$ thus progressively increased with higher target $p \mathrm{CO}_{2}$ (Fig. 6), as would be expected following the reduction in buffer capacity which would result from the initial manipulation of the carbonate chemistry system (Egleston et al., 2010). As previously indicated, variations in $A_{\mathrm{T}}$ observed through the experimental durations were less pronounced (Fig. 5).

\subsection{Net autotrophic production and nutrient dynamics}

The impact of carbonate chemistry manipulation on biogeochemical processes was assessed through observations of both biological (Chl $a, F_{\mathrm{v}} / F_{\mathrm{m}}$, organic matter production and community structure) and chemical variables $\left(C_{\mathrm{T}}, A_{\mathrm{T}}\right.$ and macronutrient concentrations). The overall nature and time course of responses varied substantially between individual experiments (Figs. 7 and 8). For example, net declines in Chl $a$ from initially high values were observed in E1 and E2, potentially indicating sampling within declining natural blooms. In contrast, net production was observed within at least some treatments for experiments E3-E5 (e.g. POC in Fig. 7 and $<10 \mu \mathrm{m} \mathrm{Chl} a$ in Fig. 8), which were initiated in warmer pico- and nanoplankton-dominated waters (Table 4). Despite considerable variability in overall dynamics, some underlying consistent responses of the natural phytoplankton communities to increasing $p \mathrm{CO}_{2}$ were observed across many of the experiments (Figs. 7 and 8). Within E3-E5, 
(a)

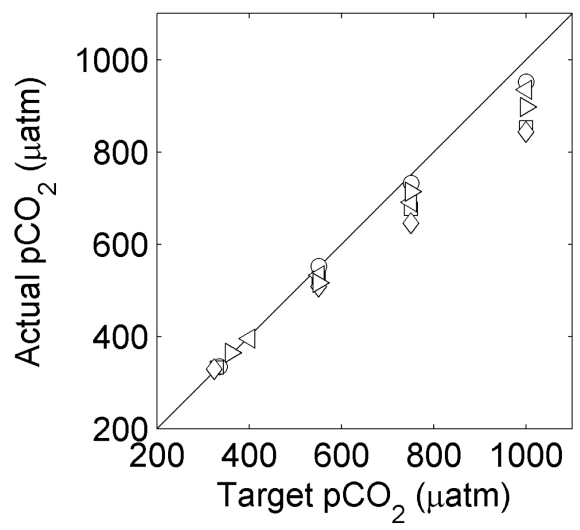

(c)

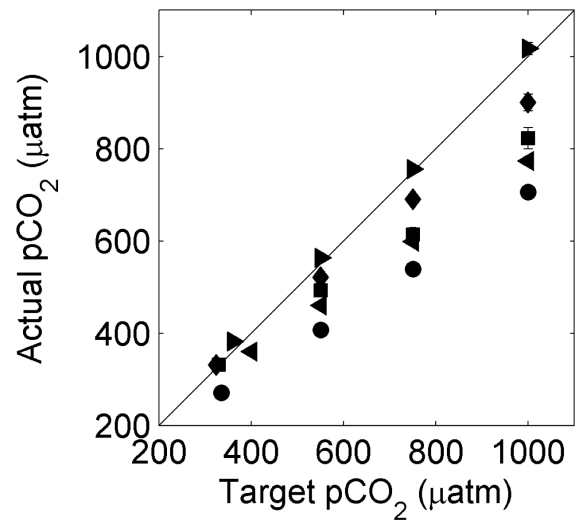

(b)

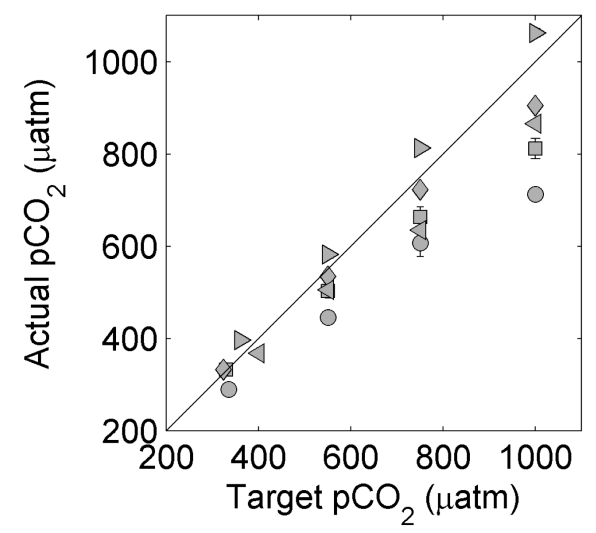

(d)

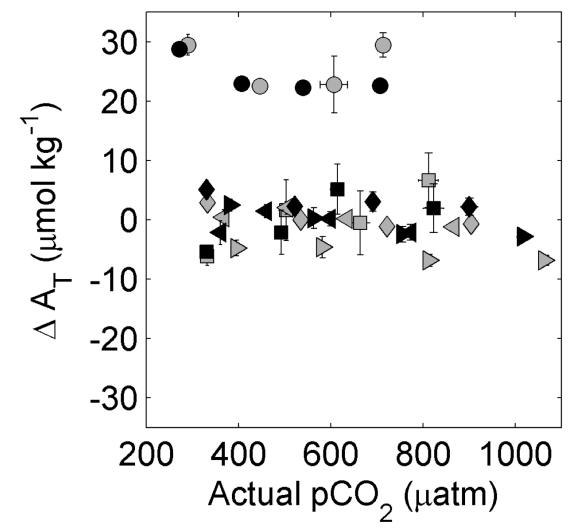

Figure 3. Carbonate chemistry evolution in the main bioassays through the incubation period. Plots illustrate targeted versus measured $p \mathrm{CO}_{2}$ ( $\mu \mathrm{atm}$ ) at (a) $T_{0}$, (b) $48 \mathrm{~h}$ and (c) $96 \mathrm{~h}$ and difference in $A_{\mathrm{T}}$ between initial and subsequent time points $\left(\Delta A_{\mathrm{T}}\right)$ (d) in all the five main bioassay experiments. Open symbols (a) indicate initial conditions, with grey (b and d) and black (c and d) symbols indicating $48 \mathrm{~h}$ and $96 \mathrm{~h}$ time points respectively. Symbol shapes indicate experiment E1 (circles), E2 (squares), E3 (diamonds), E4 (left pointing triangles) and E5 (right pointing triangles). Black lines in (a), (b) and (c) indicate the $1: 1$ line. Plotted values are means $\pm 1 \mathrm{SE}$ of biological triplicates.

increases in net phytoplankton ( $\mathrm{Chl} a$ ) biomass accumulation were observed over the first $48 \mathrm{~h}$ in the total and $<10 \mu \mathrm{m}$ $\mathrm{Chl} a$ fractions under ambient conditions (Figs. 7 and 8) and were frequently associated with increased whole community macronutrient (nitrate) consumption (Fig. 7). However, within these experiments net production progressively reduced with increasing $p \mathrm{CO}_{2}$, ultimately resulting in a switch to net loss of phytoplankton biomass $(<10 \mu \mathrm{m} \mathrm{Chl} a)$ and organic matter (POC) over $48 \mathrm{~h}$ in the 750 and $1000 \mu \mathrm{atm}$ $p \mathrm{CO}_{2}$ treatments in some cases (Figs. 7 and 8). Despite overall decreases in total Chl $a$, slightly larger declines within the high- $p \mathrm{CO}_{2}$ treatments over the first $48 \mathrm{~h}$ were also apparent in E1 (Fig. 7). Within E2, despite a lack of differences in total Chl $a$ between treatments (Fig. 7), some indication of a similar sensitivity of the smaller size fraction (Fig. 8) and pico-/nanoeukaryote numbers (Fig. 7) was also apparent. In contrast, the larger size fractions ( $>10 \mu \mathrm{m} \mathrm{Chl} a$ ) generally displayed less differential sensitivity to the imposed $p \mathrm{CO}_{2}$ manipulation (Fig. 8). Although in three experiments (E2, E3 and E4) a significant increase of the $>10 \mu \mathrm{m} \mathrm{Chl} a$ un- der the two highest $p \mathrm{CO}_{2}$ conditions could be observed by $96 \mathrm{~h}$ (Fig. 8), indicating an overall shift in community structure from small $(<10 \mu \mathrm{m})$ to larger $(>10 \mu \mathrm{m})$ cell organisms under increased $p \mathrm{CO}_{2}$.

Consequently, despite overall differences in initial biomass, the relative response of the total and $<10 \mu \mathrm{m} \mathrm{Chl} a$ fractions and pico- and nanoeukaryote numbers to increasing $p \mathrm{CO}_{2}$ within E3-E5 was remarkably consistent (Figs. 7 and 8), displaying progressively larger relative responses as the difference between the initial condition and the manipulated state increased. For these three experiments, this progressive response could be best illustrated by considering the relative differences in the various autotrophic biomass indicators (Chl $a$ and pico- and nanoeukaryote numbers) between treatments as a function of the size of the imposed perturbation as indicated, for example, by the difference in $\left[\mathrm{H}^{+}\right]$ concentration between the measurement point and the initial condition $\left(\Delta \mathrm{H}^{+}\right)$(Fig. 9). Statistically significant treatment effects (ANOVA, Tukey-Kramer, $p<0.05$ ), dominated by the responses of the $<10 \mu \mathrm{m}$ fraction (Fig. $9 \mathrm{~b}$ and d), 
(a)

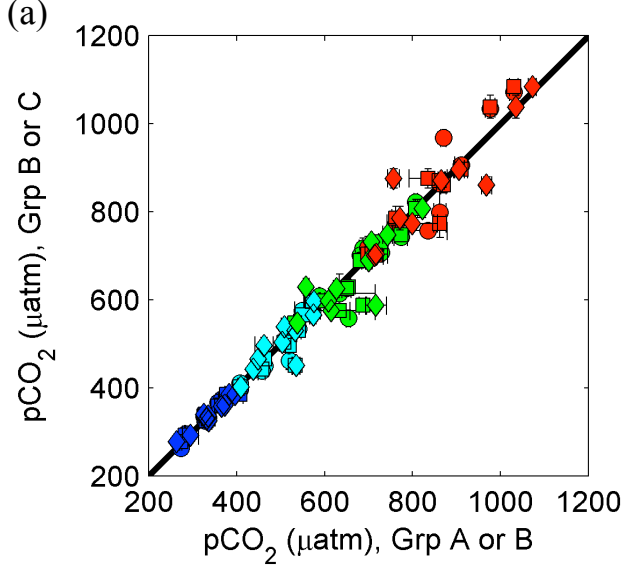

(c)

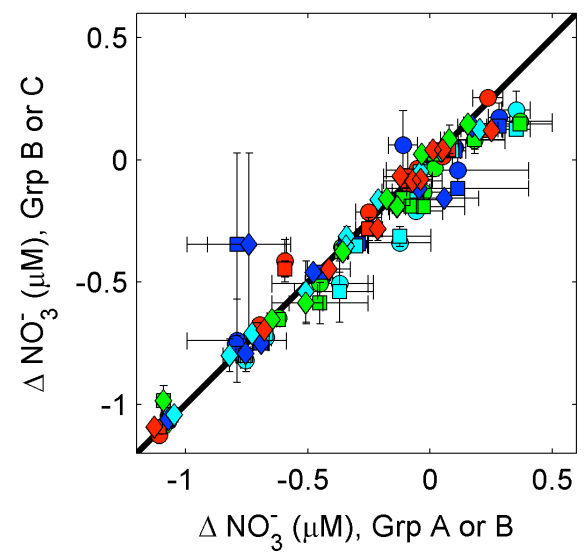

(b)

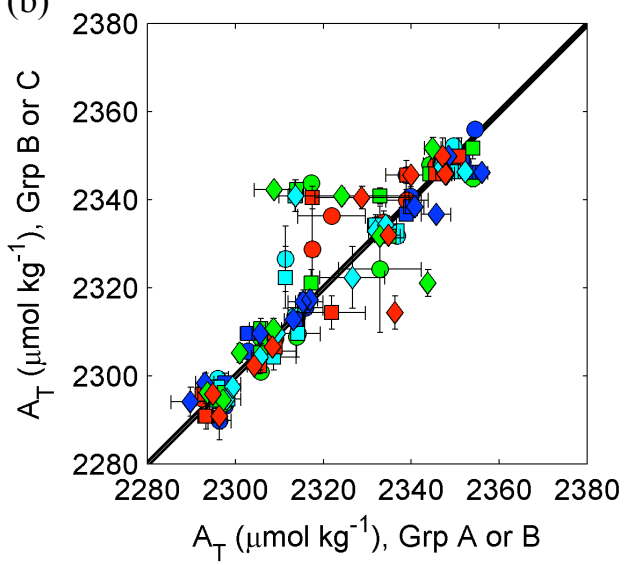

(d)

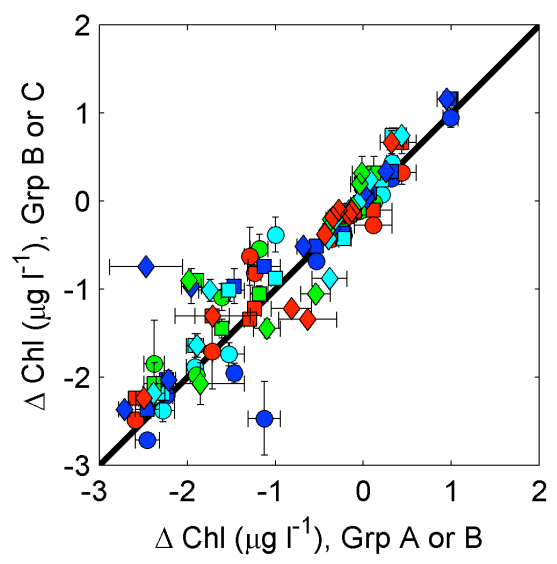

Figure 4. Comparison of variables measured across the three parallel sets of triplicate bottles (grps. A, B and C) for all main experiments: $p \mathrm{CO}_{2}(\mu \mathrm{atm})(\mathbf{a}), A_{\mathrm{T}}\left(\mu \mathrm{mol} \mathrm{kg}^{-1}\right)(\mathbf{b})$, change in nitrate concentration from initial condition $\left(\mu \mathrm{mol} \mathrm{L}{ }^{-1}\right)$ and (c) change in Chl $a$ from initial condition $\left(\mu \mathrm{g} \mathrm{L}^{-1}\right)$ (d). Plotted values are means $\pm 1 \mathrm{SE}$ of triplicate bottles in all cases. Colour indicates target $p \mathrm{CO}_{2}$ treatment (blue: ambient; cyan: $550 \mu \mathrm{atm}$; green: $750 \mu \mathrm{atm}$; red: $1000 \mu \mathrm{atm}$ ), with symbol shape indicating the following comparisons between groups: A vs. B (circles), A vs. C (squares) and B vs. C (diamonds).

(a)

Colour indicates $\Delta \mathrm{pCO}_{2}$ ( $\mu$ atm)

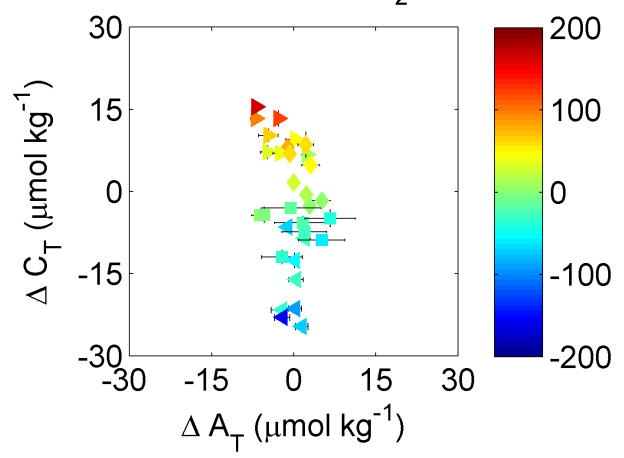

(b)

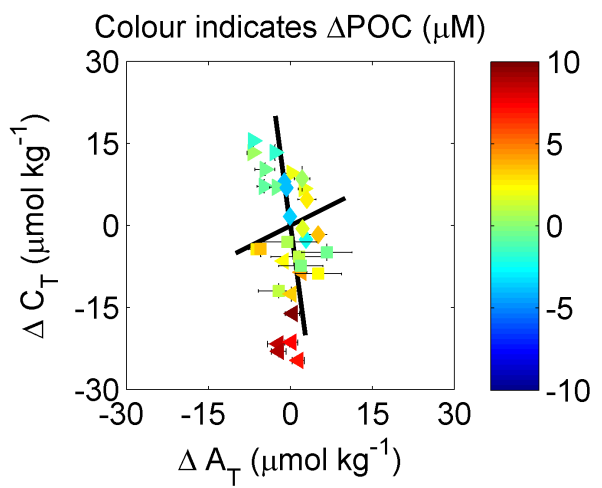

Figure 5. Scatter plots of differences between initial condition and time point samples $(\Delta)$ for the main experiments excluding E1 (i.e. E2-E5). $\Delta C_{\mathrm{T}}\left(\mu \mathrm{mol} \mathrm{kg}{ }^{-1}\right)$ is plotted against $\Delta A_{\mathrm{T}}\left(\mu \mathrm{mol} \mathrm{kg}^{-1}\right)$ with calculated changes in $p \mathrm{CO}_{2}\left(\Delta p \mathrm{CO}_{2}\right)(\mu a t \mathrm{~m})$ and measured changes in POC $(\triangle \mathrm{POC})\left(\mu \mathrm{mol} \mathrm{L}^{-1}\right)$ indicated by colours in the left and right panel, respectively. Symbol shapes indicate experiments as in Fig. 3. Plotted values are means \pm 1 SE. Black lines in (b) correspond to the predicted influence of production and remineralisation of organic material and calcite. 
(a)

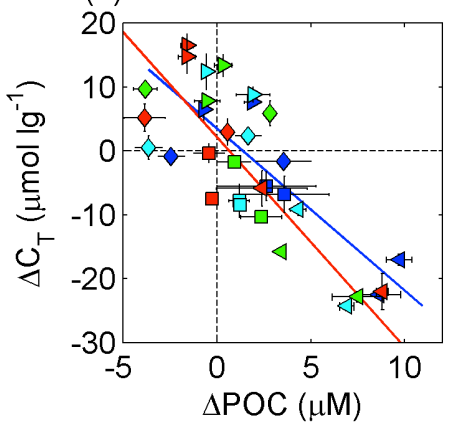

(b)

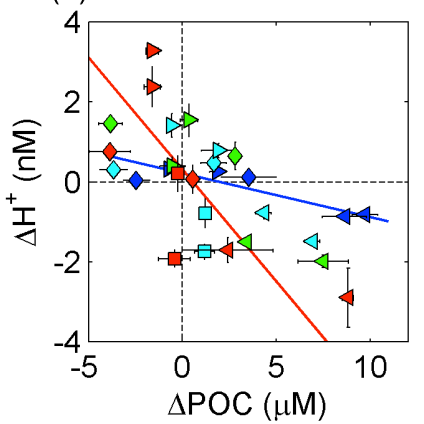

(c)

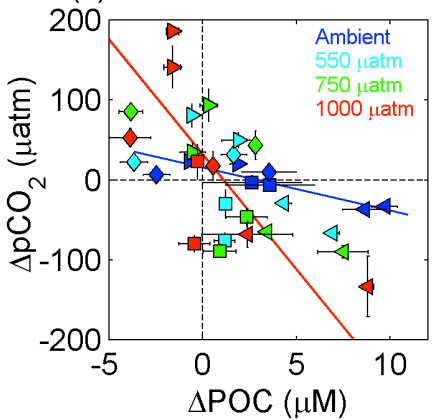

Figure 6. Scatter plots of differences in carbonate chemistry parameters against differences in POC across all time points for the main experiments excluding E1 (i.e. E2-E5): $\Delta C_{\mathrm{T}}\left(\mu \mathrm{mol} \mathrm{kg}{ }^{-1}\right)(\mathbf{a}), \Delta \mathrm{H}^{+}\left(\mathrm{nmol} \mathrm{L}{ }^{-1}\right)$ (b) and $\Delta p \mathrm{CO}_{2}$ ( $\mu$ atm) (c) are presented as a function of $\triangle \mathrm{POC}\left(\mu \mathrm{mol} \mathrm{L}{ }^{-1}\right)$. Symbol colours indicate target $p \mathrm{CO}_{2}$ treatment as in Fig. 4. Symbol shapes indicate the experiment number as in Fig. 3: E2 (squares), E3 (diamonds), E4 (left pointing triangles) and E5 (right pointing triangles) with plotted values being means $\pm 1 \mathrm{SE}$ of biological triplicates. Solid lines indicate model II linear regressions for the lowest (ambient: blue) and highest ( $1000 \mu \mathrm{atm}$ : red) $p \mathrm{CO}_{2}$ treatments. All regressions are significant $(p<0.05)$ with significant differences in slopes between the treatments presented in $(\mathbf{b})$ and $(\mathbf{c})$. Regression lines for intermediate $\mathrm{CCO}_{2}$ treatments are omitted for clarity.

E1
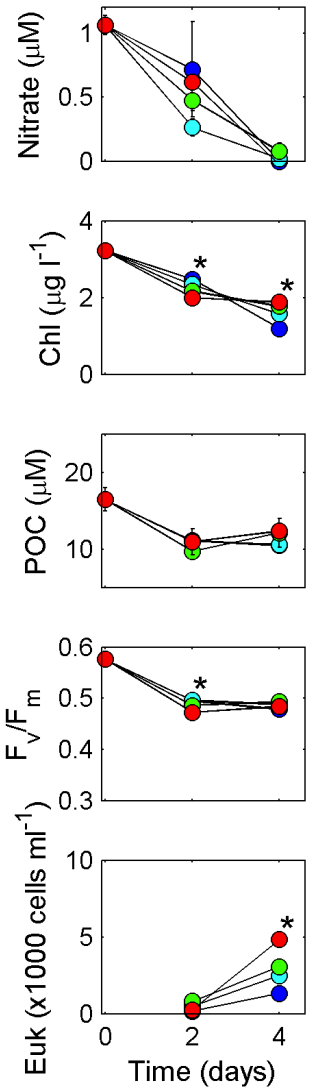

E2
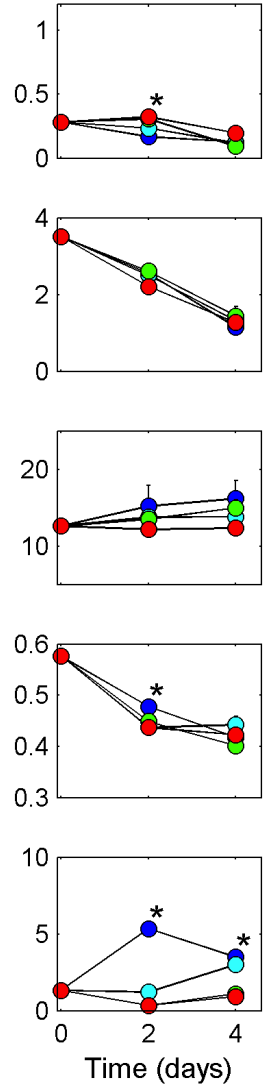

E3
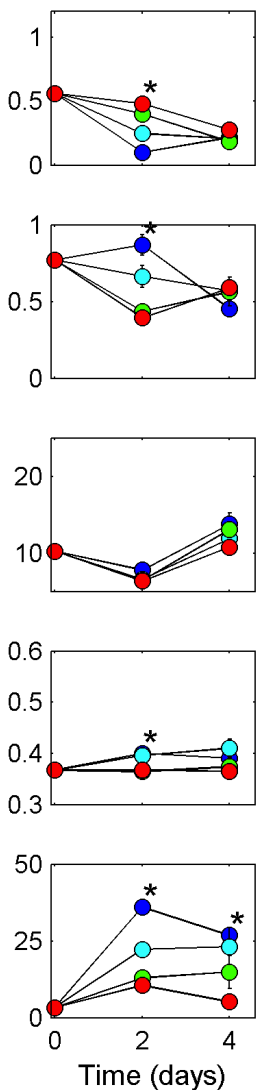

E4
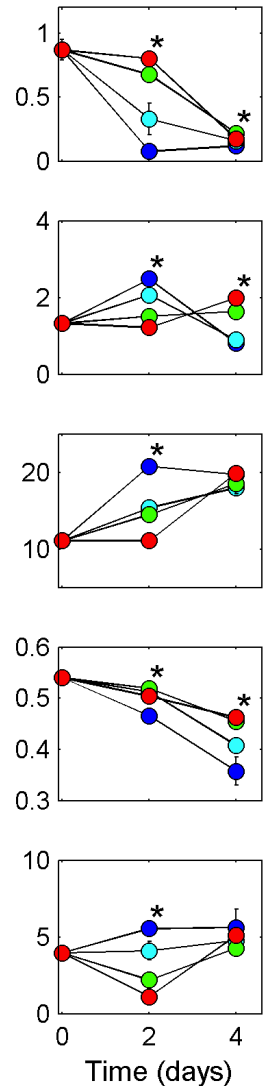

E5
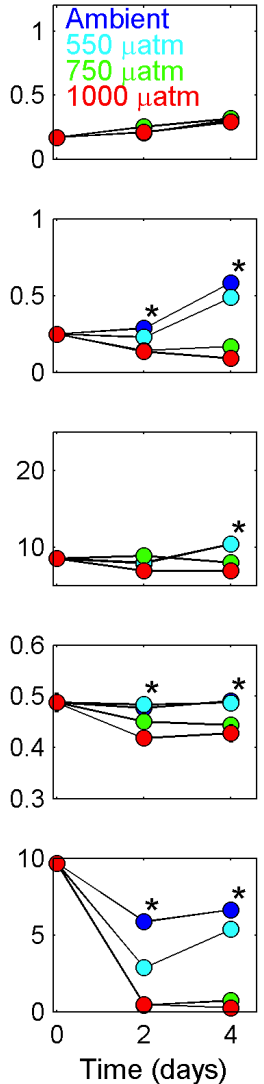

Figure 7. Time series measurements of nitrate $\left(\mu \mathrm{mol} \mathrm{L}{ }^{-1}\right)$, total Chl $a\left(\mu \mathrm{g} \mathrm{L}^{-1}\right)$, particulate organic carbon $(\mathrm{POC})(\mu \mathrm{mol} \mathrm{L}-1)$, photosynthetic efficiency $\left(F_{\mathrm{V}} / F_{\mathrm{m}}, \mathrm{FRRf}\right)$ and pico- and nanoeukaryote counts (cell $\left.\times 1000 \mathrm{~mL}^{-1}\right)$ from the main experiments (E1-E5). Plotted values are means $\pm 1 \mathrm{SE}$, for biological triplicates. Where error bars are not visible, these are smaller than the symbol size. Note differences in scales for chlorophyll and cell count measurements. Observation of any statistically significant differences between treatments (one-way ANOVA, $p<0.05)$ for each variable and time point are indicated by “*”. The detailed results of subsequent Tukey-Kramer means comparison tests are omitted for clarity. 

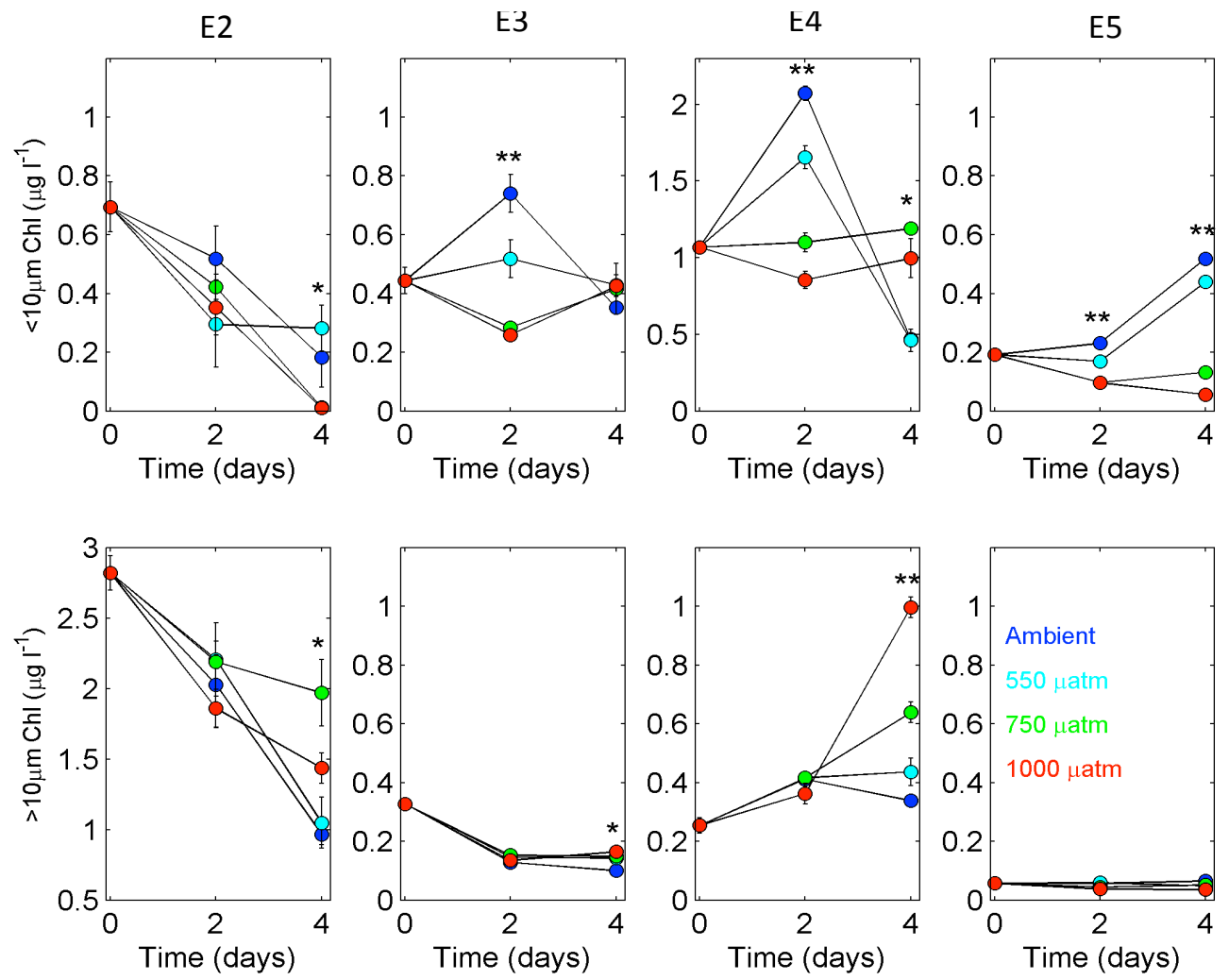

Figure 8. Time series measurements of size-fractionated Chl $a(<10 \mu \mathrm{m}$ and $>10 \mu \mathrm{m})\left(\mu \mathrm{g} \mathrm{L}^{-1}\right)$ from main experiments (E2-E5). At each time point, statistical differences between treatments were evaluated using one-way ANOVA followed by a Tukey-Kramer means comparison test. Sets of measurements where at least one treatment was statistically different $(p<0.05)$ are indicated by “*”, while sets where there is a clear progressive response as a function of treatment (i.e. where at least three groups could be distinguished between the four incubation conditions and where the effect consistently increased/decreased as a function of $p \mathrm{CO}_{2} / \mathrm{pH}$ ) are indicated by “**”.

could be observed even under the lowest manipulation level $(550 \mu \mathrm{atm})$, while no effect was observed for larger cells (Fig. 9c). Consideration of responses against the magnitude of the imposed chemical perturbation further allowed comparison with the approximate ranges of cell surface $\left[\mathrm{H}^{+}\right]^{\text {prox }}$ likely encountered by cells over short timescales (i.e. hour, days) under modern and $750 \mu$ atm $p \mathrm{CO}_{2}$ conditions (Flynn et al., 2012) (Fig. 9b and c). Thus, while perturbations were far in excess of likely $\left[\mathrm{H}^{+}\right]^{\text {prox }}$ variability for the smaller size fractions (Fig. 9b), they were potentially comparable to those naturally encountered by the largest microbial size fractions.

By the end of the experimental time courses, whole community uptake had frequently fully removed ambient nitrate, likely resulting in subsequent secondary biological responses to nutrient depletion (Fig. 7). In many cases these apparent secondary responses cascaded through the system at different times across different treatments, reflecting any initial influence of the $p \mathrm{CO}_{2}$ manipulation on the net biomass uptake and nutrient drawdown (Fig. 7); i.e. reduced growth/biomass accumulation with elevated $p \mathrm{CO}_{2}$ frequently resulted in slower macronutrient depletion. This nutrient starvation feedback effect was perhaps most evident within E4 (Fig. 7), where the depletion of nitrate at different times within the different treatments was always accompanied by a reduction in the apparent photochemical efficiency of photosystem II $\left(F_{\mathrm{v}} / F_{\mathrm{m}}\right)$, as frequently accompanies nutrient starvation (Suggett et al., 2009), alongside a subsequent cessation in net biomass accumulation (Figs. 7 and 8). Overall, the presence of secondary feedback effects, despite the short duration of our experimental protocol, clearly illustrates the potential difficulties in differentiating direct from indirect effects over progressively increasing timescales in ocean acidification experiments. For example, treatment effects observable at $48 \mathrm{~h}$ had often collapsed (E3), or even reversed in sense (E4), by $96 \mathrm{~h}$ (Figs. 7 and 8), likely reflecting the dominance of nutrient depletion in the majority of the main experiments by that stage. Such potentially confounding influence of nutrient exhaustion will likely occur in any natural system and frequently necessitates additional system perturbation via nutrient amendment in longer-term experiments (Riebesell et al., 2013; Brussaard et al., 2013). However, for the current study, reproducible responses, characterised by a reduction of net growth by the smaller phytoplankton size fractions, were observed within experiments 
(a)

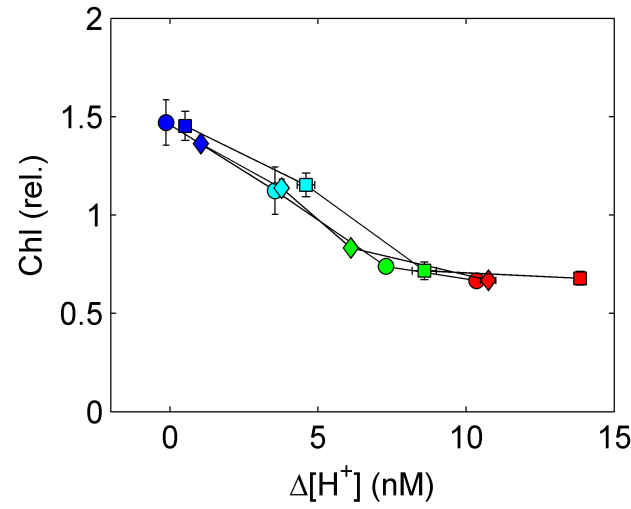

(c)

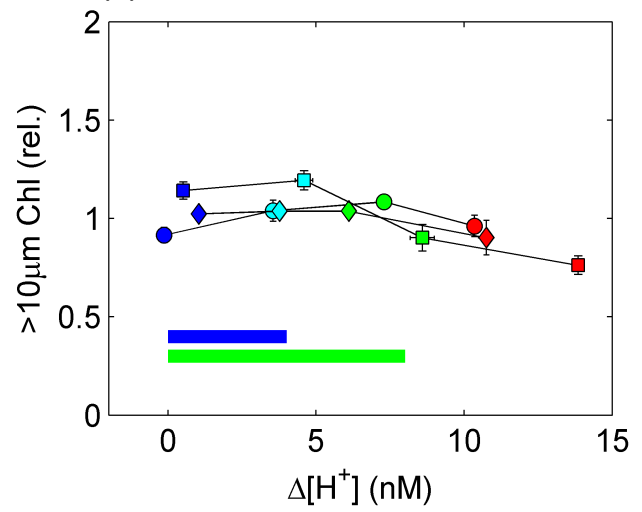

(b)

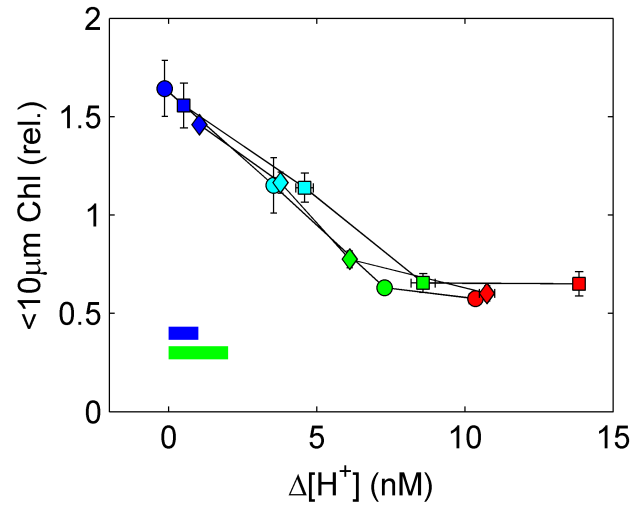

(d)

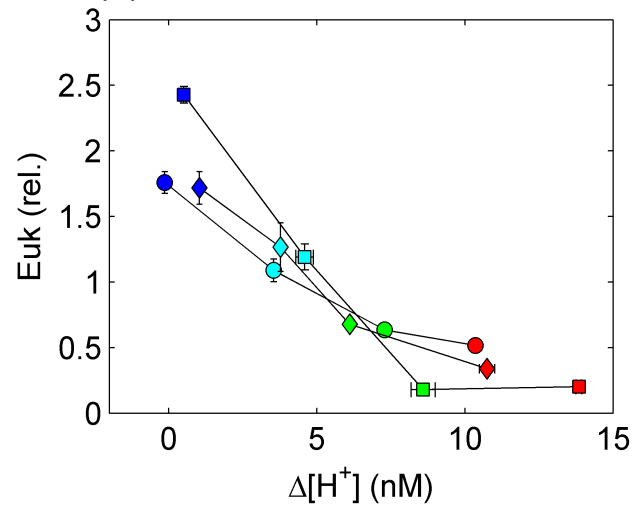

Figure 9. Relative changes in total (a), $<10 \mu \mathrm{m}$ (b) and $>10 \mu \mathrm{m}$ (c) size-fractionated Chl $a$ and nano-/picoeukaryotes counts (d) as a function the change in $\left[\mathrm{H}^{+}\right]$after $48 \mathrm{~h}$ incubation in three (E3-E5) out of the five main bioassay experiments. Data for each variable are normalised to the mean value for this time point and plotted against the difference in $\left[\mathrm{H}^{+}\right]^{\text {bulk }}$ between the ambient incubation and the treatment. Values plotted are mean \pm 1 SE for both axes. Solid bars in (b) and (c) indicate approximate ranges of cell surface $\left(\left[\mathrm{H}^{+}\right]^{\text {prox }}\right)$ which might be experienced by small and large cells over short timescales, i.e. hours-days (see Kuhn and Raven 2008; Flynn et al., 2012), under ambient modern conditions (blue) and at $\sim 750 \mu$ atm (green) (Flynn et al., 2012). Colours indicate treatment conditions as in Fig. 7.

having both relatively high (e.g. E4) and low (e.g. E5) starting macronutrient concentrations (Table 2).

Evidence for phytoplankton nutrient (co-)limitation under ambient conditions was apparent in two of the three combined nutrient addition-carbonate chemistry manipulation experiments (Fig. 10). Specifically, within both the experiments initiated in relatively low ambient nutrient $(<0.3 \mu \mathrm{M}$ $\mathrm{NO}_{3}^{-}$) waters (E4b and $\mathrm{E} 5 \mathrm{~b}$ ), the addition of $\mathrm{NO}_{3}^{-}$, either alone $(+\mathrm{N})$ or in combination with $\mathrm{PO}_{3}^{-}(+\mathrm{NP})$, resulted in increased productivity and phytoplankton biomass (Fig. 10). In contrast, there was no apparent nutrient response within E2b, which was initiated in waters containing relatively high ambient macronutrients (Table 2). Importantly, although addition of potentially (co-)limiting macronutrients $(+\mathrm{N}$ or $+\mathrm{NP}$ ) increased community biomass and productivity in two of the experiments, overall productivity and total and $<10 \mu \mathrm{m}$ Chl $a$ concentrations fraction were significantly altered by manipulation of the carbonate chemistry system. These significant responses were observed under both ambient and experimentally induced high-nutrient conditions across all these additional factorial experiments (Fig. 10). In contrast, despite also responding to nutrient amendment in $\mathrm{E} 4 \mathrm{~b}$ and $\mathrm{E} 5 \mathrm{~b}$, the larger phytoplankton were once again less sensitive to $p \mathrm{CO}_{2}$, with reduced (E2b) or insignificant (E4b and E5b) $p \mathrm{CO}_{2}$ treatment effects observed for the $>10 \mu \mathrm{m}$ Chl $a$ concentration (Fig. 10). Overall the results of the additional combined nutrient-carbonate chemistry manipulation experiments (Fig. 10) were thus consistent with the results from the main experiments, particularly E3-E5 (Figs. 7 and 8).

\section{Discussion}

\subsection{Performance of experimental method}

The approach adopted here differed in a number of respects from many previous field-based experimental studies examining the potential effects of ocean acidification on phytoplankton ecophysiological processes and subsequent 

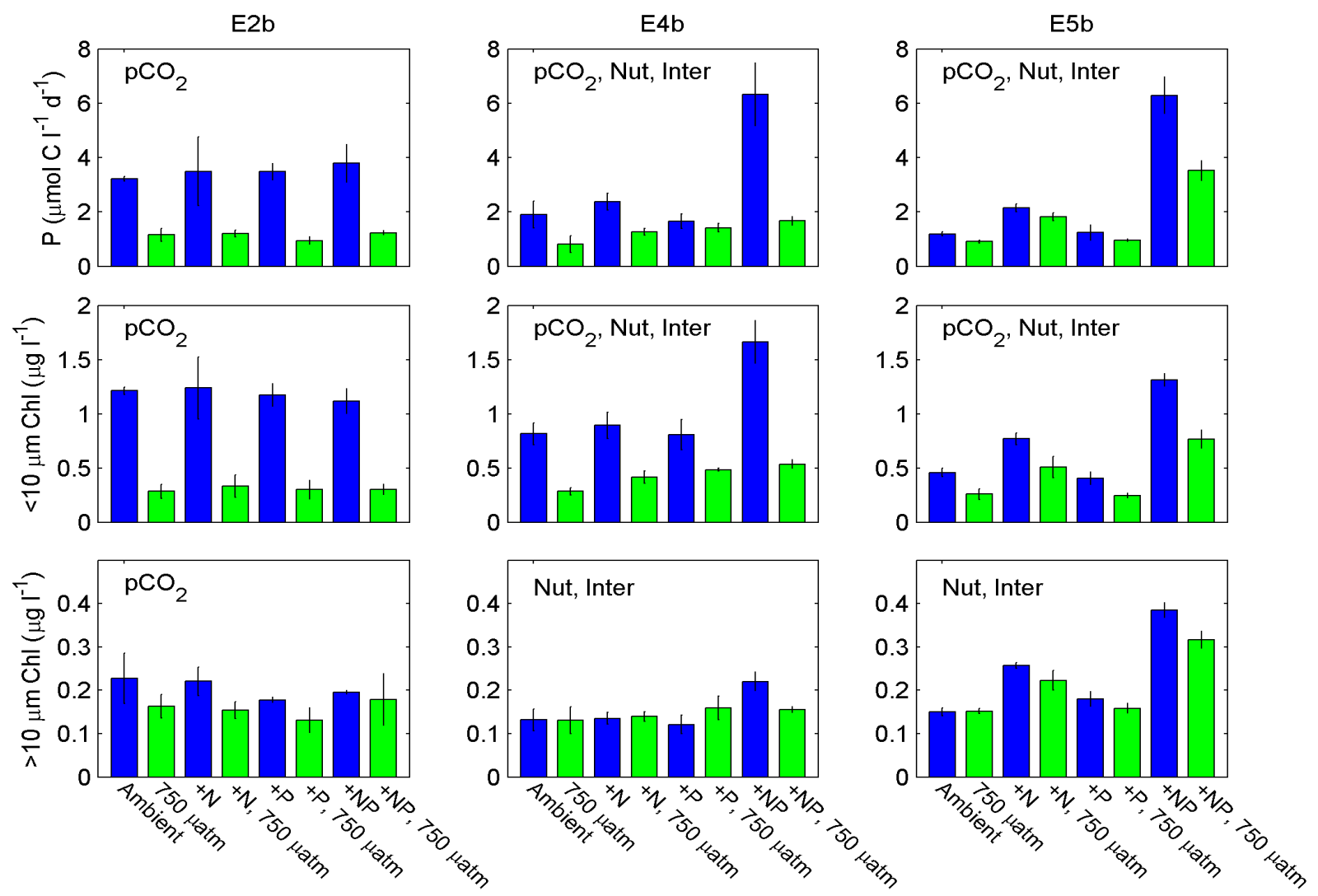

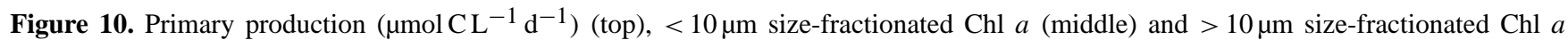
$\left(\mu \mathrm{g} \mathrm{L}^{-1}\right)$ (bottom) from the additional combined macronutrient and carbonate chemistry manipulation experiments (E2b, E4b and E5b). Data are presented as means $\pm 1 \mathrm{SE}$ of biological triplicates for each variable after $24 \mathrm{~h}$ incubation under ambient or $750 \mu$ atm $p \mathrm{CO}_{2}(\mathrm{colours}$ as in Fig. 7) and under either unamended or nutrient-amended $(+\mathrm{N},+\mathrm{P}$ and $+\mathrm{NP})$ conditions. Individual panels are annotated with the results of a two-way ANOVA, with " $p \mathrm{CO}_{2}$ ", "Nut" and "Inter" indicating significant $(p<0.05)$ differences between factors corresponding to the imposed perturbation of the carbonate system, macronutrients and an interaction between these factors respectively.

biogeochemical cycling. In contrast to many studies (e.g. Hare et al., 2007; Feng et al., 2009; Lomas et al., 2012; Riebesell et al., 2013), with the exception of the additional experiments (Fig. 10), we largely investigated natural communities without the supplementary addition of nutrients. The resulting necessary restriction on experimental duration was thus traded off against the incubations being performed at realistic natural nutrient levels. The restricted experimental durations also allowed more experiments to be performed over the period of the cruise, facilitating a better consideration of the so-called "sampling universe" (Ridgwell et al., 2009). Consequently, we could assess the responses of intact microbial communities sampled from eight geographical locations, representing a significant increase on even the most extensive prior studies (e.g. Hopkinson et al., 2010), further allowing us to assess the generality of any observed responses. The enhanced spatio-temporal scale, coupled to high statistical power, allowed rigorous assessment of within and between experiment reproducibility for multiple variables. The high reproducibility of within experiment obser- vations indicated robust and repeatable biogeochemical responses both to the overall containment of the natural community and to the carbonate chemistry manipulations performed (Figs. 3 and 4). Moreover, the large suite of variables measured (up to 39, Table 3, Richier et al., 2014), provides the potential to investigate primary and secondary responses of complex natural microbial communities and resultant effects on biogeochemical cycling.

\subsection{Well-constrained carbon cycling}

In the majority of cases (i.e. excluding E1), the adopted carbonate chemistry manipulation allowed us to successfully increase total $C_{\mathrm{T}}$ without changes in $A_{\mathrm{T}}$, as is predicted to occur as a result of ongoing ocean acidification (e.g. Orr et al., 2005). Small $A_{\mathrm{T}}$ variations observed in the experiments over the time course (Fig. 5) were potentially attributable to nitrate uptake or carbonate mineral precipitation/dissolution (Cross et al., 2013). Specific to calcite, coccolithophores were a consistent, although relatively minor, component of phytoplankton communities collected through the experiments (Young 
et al., 2014), with CP significantly increasing in response to nutrient addition under ambient $p \mathrm{CO}_{2}$ only (Poulton et al., 2014). Irrespective of the treatments applied to the diverse microbial communities, changes in $C_{\mathrm{T}}\left(\Delta C_{\mathrm{T}}\right)$ were strongly correlated to the net production or remineralisation of POC (Fig. 6). Remaining deviation between $C_{\mathrm{T}}$ drawdown and POC accumulation could potentially be the result of a release of dissolved organic carbon (DOC) and/or formation of transparent exopolymer particles (TEP) as suggested in previous studies (Antia et al., 1963; Sambrotto et al., 1993; Riebesell et al., 2007). Within the current experiments, no significant treatment-dependent changes in total DOC accumulation could be observed, although TEP did vary as a function of experimental treatment within some experiments (MacGilchrist et al., 2014).

\subsection{Size-related physiological responses}

Significant responses of phytoplankton to changes in carbonate chemistry were observed in all the eight experiments performed (Figs. 7, 8 and 10), although the magnitude of treatment effects was considerably reduced in E1 and E2 (Fig. 7). For the three main experiments where the community was dominated by $<10 \mu \mathrm{m}$ cells (E3-E5), bulk community variables (Figs. 7 and 8 ) demonstrated a clear sensitivity to rapid changes in $\left[\mathrm{H}^{+}\right]$and $p \mathrm{CO}_{2}\left(\Delta\left[\mathrm{H}^{+}\right]\right.$and $\left.\Delta p \mathrm{CO}_{2}\right)$, with a relative decrease in net biomass accumulation which scaled with increasing manipulation away from the ambient condition (Fig. 9). In addition, size-fractionated responses within all the strongly responding experiments confirmed that the small size fraction $(<10 \mu \mathrm{m} \mathrm{Chl} a)$ was both the most sensitive to the imposed carbonate chemistry perturbation and was largely responsible for the observed bulk responses (Figs. 7-10). In contrast, experiments initiated within communities rich in large-celled taxa (E1 and E2) displayed weaker responses. As in previous studies (Eggers et al., 2014; Yoshimura et al., 2013), initial community composition may therefore have influenced the nature and magnitude of the observed responses to elevated $p \mathrm{CO}_{2}$.

The observed short-term negative responses to increased $p \mathrm{CO}_{2}$ for the smaller size classes (Figs. 8 and 9) contrasted with previous observations of enhanced biomass for smaller size classes over longer timescales in a previous mixed community experiment (Brussaard et al. 2013). Other field evidence has also suggested enhanced positive responses to enhanced $p \mathrm{CO}_{2}$ for larger cells, in particular diatoms (Feng et al., 2009; Yoshimura et al., 2013; Eggers et al., 2014). The mechanistic basis for the latter cases potentially relates to diffusion limitation of $\mathrm{CO}_{2}$ uptake and hence an enhanced reliance on CCMs which can be down-regulated under higher $p \mathrm{CO}_{2}$ (Wu et al. 2014).

Within mixed communities, even over short timescales, complex ecosystem interactions may influence the results of any manipulation experiment. For example, within E4 (Figs. 7 and 8), an apparent positive response of the larger
$>10 \mu \mathrm{m}$ fraction to increasing $p \mathrm{CO}_{2}$ could be observed by $48 \mathrm{~h}$ (Fig. 8). However it remains unclear whether this represented a direct sensitivity to increasing $p \mathrm{CO}_{2}$, as might be expected (Wu et al., 2014), or potentially an ecological effect resulting from reduced competition due to the observed more immediate negative responses for the $<10 \mu \mathrm{m}$ fraction (Fig. 8). The potential for such complexity within natural community experiments, combined with evidence of differences in both the degree of overall sensitivity and extent of differential sensitivity between phytoplankton groups (Brussaard et al., 2013; Eggers et al., 2014; Yoshimura et al., 2013), further emphasises the importance of developing conceptual mechanistic models for any observed phenomenological responses to carbonate chemistry manipulation.

It is not possible to unequivocally relate the responses, which were observed consistently across the majority of experiments to a specific physiological mechanism. However, we suggest that an enhanced sensitivity of small-celled phytoplankton to the imposed rapid shifts in carbonate chemistry would be consistent with cell-size-specific differences in levels of adaptation to naturally experienced fluctuations in carbonate chemistry species within the environment (Flynn et al., 2012). Specifically, the variability in $\left[\mathrm{H}^{+}\right]^{\text {prox }}$ (or indeed other related carbonate chemistry variables such as $p \mathrm{CO}_{2}^{\text {prox }}$ or $\mathrm{CO}_{3}^{2-\text { prox }}$ ) experienced by phytoplankton should scale with phytoplankton cell size (Flynn et al., 2012), with smaller-celled taxa expected to encounter relatively restricted $\Delta\left[\mathrm{H}^{+}\right]^{\text {prox }}$ compared to larger cells or aggregates, due to a reduced diffusive boundary layer (Flynn et al., 2012). Subsequently, variability in $\left[\mathrm{H}^{+}\right]^{\text {prox }}$ might impact cell physiology in a number of ways, for example, influencing nutrient transport and internal $\mathrm{pH}$ regulation (Milligan, 2012).

Consequently, consistent with our observations (Fig. 9), we suggest that smaller-celled taxa might be expected to have a higher sensitivity to our experimentally induced perturbations of $\left[\mathrm{H}^{+}\right]^{\text {bulk }}$ (and hence $\left[\mathrm{H}^{+}\right]^{\text {prox }}$ ), which were likely outside the naturally experienced range of $\left[\mathrm{H}^{+}\right]^{\text {prox }}$. Imposed changes in $\left[\mathrm{H}^{+}\right]^{\text {bulk }} /\left[\mathrm{H}^{+}\right]^{\text {prox }}$ could thus result in shortterm detrimental effects on cellular processes and hence ultimately overall growth. In contrast, larger cells will naturally experience, and thus presumably be better adapted to, rapid changes in $\left[\mathrm{H}^{+}\right]^{\text {prox }}$ (Flynn et al., 2012). Hence we might expect larger-celled phytoplankton to be more capable of dealing with an imposed rapid experimental manipulation of $\left[\mathrm{H}^{+}\right]^{\text {bulk }}$ without this having a major direct influence on cellular processes, again consistent with our observations (Figs. 8 and 9). Indeed, we note that modelled natural diel ranges of variability in $\left[\mathrm{H}^{+}\right]^{\text {prox }}$ for the largest size classes (Flynn et al., 2012), although only indicative of extremes, are reasonably comparable in magnitude to our experimentally imposed $\Delta\left[\mathrm{H}^{+}\right]^{\text {bulk }}$ (Fig. 9).

In addition to the initially imposed $\Delta\left[\mathrm{H}^{+}\right]^{\text {bulk }}$, as expected (Delille et al., 2005; Riebesell et al., 2007; Egleston et al., 2010; Hopkins et al., 2010), the buffer capacity decreased as 
a function of increasing $p \mathrm{CO}_{2}$ (Fig. 6). Decreased buffering would then result in increased diel and longer-term $\Delta\left[\mathrm{H}^{+}\right]^{\text {prox }}$ (and $\Delta p \mathrm{CO}_{2}^{\text {prox }}$ ) as well as $\Delta\left[\mathrm{H}^{+}\right]^{\text {bulk }}$ (and $\Delta p \mathrm{CO}_{2}^{\text {bulk}}$ ) (Flynn et al., 2012) potentially further disadvantaging any taxa without a high pre-existing adaptation to such variability in the higher- $p \mathrm{CO}_{2}$ treatments. Overall, we thus argue that our results are consistent with the suggestion of Flynn et al. (2012) that size-dependent differential susceptibility to changes in $\left[\mathrm{H}^{+}\right]$might need to be considered in the design of experiments to investigate ocean acidification, interpretation of the results of such experiments and potentially in prediction of community structure responses to ongoing and future anthropogenic forcing (Milligan, 2012).

\subsection{Biogeochemical feedbacks in the future ocean}

Surface ocean carbonate chemistry is naturally subjected to considerable variability driven by multiple factors, including net photosynthesis and respiration from microbial activity (Joint et al., 2011; Patsch and Lorkowski, 2013). Simultaneously, multiple lines of research into the potential influence of ocean acidification on marine systems, including the evidence presented here, have revealed the potential for variations in different components of the carbonate chemistry system (e.g. $p \mathrm{CO}_{2}$ level, carbonate ion and $\mathrm{H}^{+}$concentrations) to influence the biological activity of marine microbes (Liu et al., 2010; Riebesell and Tortell, 2011). Consequently, the biogeochemical dynamics of natural oceanic systems might be expected to be influenced by reciprocal interactions between carbonate chemistry and microbial activity.

Accurate prediction of the overall microbial responses to altered carbonate chemistry in a future ocean are still hampered by the lack of clearly identifiable consistent physiological responses across multiple experimental studies and scales (Hofmann et al., 2010; Riebesell and Tortell, 2011; Wernberg et al., 2012). In contrast, as oceanic anthropogenic carbon uptake continues into the future, resulting changes in bulk carbonate chemistry, alongside the range of variability in the carbonate chemistry system which will result from any given biological process (Fig. 6), are reasonably well understood and predictable (Egleston et al., 2010). Thus, in addition to any direct microbial/biogeochemical responses to altered bulk values of carbonate chemistry parameters, the nature of any natural carbonate biogeochemical feedbacks might be expected to be altered into the future. Consequently, in addition to evaluating overall sensitivities of microbes to the state of the carbonate system (Joint et al., 2011) and assessing the potential of individual microbial strains and communities to adapt to ongoing change (Doney et al., 2009), future studies should perhaps pay more attention to identifying the significance of any existing natural feedbacks.

Recognition of such potential feedbacks also serves to further highlight that, as within any experimental study (Doney et al., 2009), extrapolation of the presented data to ongoing anthropogenic ocean acidification needs to be undertaken with care. The short-timescale sensitivities to rapid carbonate chemistry manipulation we observed would not be expected to be directly translatable to the many orders of magnitude slower forcing that natural phytoplankton communities will encounter as a result of ocean acidification (Table 1) (Collins, 2011). Phytoplankton are characterised by differential plasticity to environmental forcing, likely including changes in $\left[\mathrm{H}^{+}\right]$and $p \mathrm{CO}_{2}$ (Schaum et al., 2013), alongside generation times which are short enough to potentially allow a degree of evolutionary adaptation to the slow anthropogenic build-up of $\mathrm{CO}_{2}$ (Collins and Bell, 2006; Lohbeck et al., 2012; Reusch and Boyd, 2013). Consequently, any cell-sizespecific sensitivity to variability in $\left[\mathrm{H}^{+}\right]$(or other carbonate species), as suggested by models (Flynn et al., 2012) and supported by our experiments (Figs. 8-10), might be expected to represent a further mechanism by which ocean acidification could drive slow changes in phytoplankton communities, through some combination of ecological and/or evolutionary processes (Milligan, 2012; Schaum et al., 2013).

\section{Conclusions}

Within the current study we observed phytoplankton responses to deliberate rapid changes in carbonate chemistry, using an experimental setup offering high replication and hence the potential for robust statistical analysis and reproducibility (Krause et al., 2012). Our study design thus facilitated sampling across a reasonably large, albeit still relatively constrained, geographical scale and range of environmental conditions. Despite variability in the phytoplankton responses across the different sites, a consistent trend was observed in the majority of experiments, which appeared to be driven by the suppressed activity of small phytoplanktonic cells following rapid $\mathrm{H}^{+}$(and/or $p \mathrm{CO}_{2}$ changes). The observed responses were largely independent of initial or perturbed nutrient concentrations. Rapid increases in $p \mathrm{CO}_{2}$ thus had a short-term negative influence on net phytoplankton production, which was progressive and reproducible, albeit with some degree of inter-experiment variability. Such increased sensitivity of small-celled phytoplankton groups to short-term increases in $p \mathrm{CO}_{2}$ is consistent with some theoretical considerations (Flynn et al., 2012). Variability in responses between experiments may then be speculated to relate to differences in initial community composition and/or size structure or potentially other environmental factors, including the initial state of the carbonate chemistry system and hence buffering capacity.

Acknowledgements. This work was funded under the UKOA programme via NERC grants NE/H017348/1 to T. Tyrrell, E. P. Achterberg and C. M. Moore; NE/H017097/1 to A. J. Poulton and M. V. Zubkov; and NE/H017062/1 to D. J. Suggett. We would like to thank the crew of the RRS Discovery, the technical staff from the National Marine Facilities, Mark Stinchcombe (NOC) 
for macronutrient data, Michelle Bennett (NOC) for Lugol's count data and Ross Holland (NOC) for flow cytometry data. Further thanks go to Rob Thomas (BODC) for data management. Finally, we would like to thank the Editor J.-P. Gattuso and two anonymous reviewers for their helpful comments which greatly improved the manuscript.

\section{Edited by: J.-P. Gattuso}

\section{References}

Antia, N. J., McAllister, C. D., Parsons, T. R., Stephens, K., and Strickland, J. D. H.: Further measurements of primary production using a large-volume plastic sphere, Limnol. Oceanogr., 8, 166183, 1963.

Archer, S. D., Kimmance, S. A., Stephens, J. A., Hopkins, F. E., Bellerby, R. G. J., Schulz, K. G., Piontek, J., and Engel, A.: Contrasting responses of DMS and DMSP to ocean acidification in Arctic waters, Biogeosciences, 10, 1893-1908, doi:10.5194/bg10-1893-2013, 2013.

Badr, E.-S. A., Achterberg, E. P., Tappin, A. D., Hill, S. J., and Braungardt, C. B.: Determination of dissolved organic nitrogen in natural waters using high-temperature catalytic oxidation, Trac-Trend. Anal. Chem., 22, 819-827, 2003.

Barry, J. P., Tyrrell, T., Hansson, L., Plattner, G.-K., and Gattuso, J.-P.: Atmospheric $\mathrm{CO}_{2}$ targets for ocean acidification perturbation experiments, in: Riebesell, U., Fabry, V. J., Hansson, L., and Gattuso, J. P.: Guide to Best Practices for Ocean Acidification Research and Data Reporting, Publications Office of the European Union, Luxembourg, 263 pp., 2010.

Brussaard, C. P. D., Noordeloos, A. A. M., Witte, H., Collenteur, M. C. J., Schulz, K., Ludwig, A., and Riebesell, U.: Arctic microbial community dynamics influenced by elevated $\mathrm{CO}_{2}$ levels, Biogeosciences, 10, 719-731, doi:10.5194/bg-10-719-2013, 2013.

Caldeira, K. and Wickett, M. E.: Oceanography: anthropogenic carbon and ocean pH, Nature, 425, 365-365, 2003.

Ciais, P., Sabine, C., Bala, G., Bopp, L., Brovkin, V., Canadell, J., Chhabra, A., DeFries, R., Galloway, J., Heimann, M., Jones, C., Le Quéré, C., Myneni, R. B., Piao, S., and Thornton, P.: Carbon and other biogeochemical cycles, in: Climate Change 2013: The Physical Science Basis, Contribution of Working Group I to the Fifth Assessment Report of the Intergovernmental Panel on Climate Change, edited by: Stocker, T. F., Qin, D., Plattner, G.-K., Tignor, M., Allen, S. K., Boschung, J., Nauels, A., Xia, Y., Bex, V., and Midgley, P. M., Cambridge University Press, Cambridge, UK, New York, NY, USA, 2013.

Clark, D. R., Rees, A. P., and Joint, I.: A method for the determination of nitrification rates in oligotrophic marine seawater by gas chromatography/mass spectrometry, Mar. Chem., 103, 8496, 2007.

Clark, D. R., Brown, I. J., Rees, A. P., Somerfield, P. J., and Miller, P. I.: The influence of ocean acidification on nitrogen regeneration and nitrous oxide production in the North-West European shelf sea, Biogeosciences Discuss., 11, 3113-3165, doi:10.5194/bgd-11-3113-2014, 2014.

Collins, S.: Competition limits adaptation and productivity in a photosynthetic alga at elevated $\mathrm{CO}_{2}$, P. Roy. Soc. B-Biol. Sci., 278, 247-255, 2011.
Collins, S. and Bell, G.: Evolution of natural algal populations at elevated $\mathrm{CO}_{2}$, Ecol. Lett., 9, 129-135, 2006.

Cross, J. N., Mathis, J. T., Bates, N. R., and Byrne, R. H.: Conservative and non-conservative variations of total alkalinity on the southeastern Bering Sea shelf, Mar. Chem., 154, 100-112, 2013.

Cullen, J. and Davis, R.: The blank can make a big difference in oceanographic measurements, Limnol. Oceanogr.-Bull., 12, 2935, 2003.

Delille, B., Harlay, J., Zondervan, I., Jacquet, S., Chou, L., Wollast, R., Bellerby, R. G. J., Frankignoulle, M., Borges, A. V., Riebesell, U., and Gattuso, J.-P.: Response of primary production and calcification to changes of $p \mathrm{CO}_{2}$ during experimental blooms of the coccolihophorid Emiliania huxleyi, Global Biochem. Cy., 19, GB2023, doi:10.1029/2004GB002318, 2005.

Doney, S. C., Fabry, V. J., Feely, R. A., and Kleypas, J. A.: The other $\mathrm{CO}_{2}$ problem, Annual Review of Marine Science, 1, 169192, 2009.

Dickson, A. G. and Millero, F. J.: A comparison of the equilibrium constants for the dissociation of carbonic acid in seawater media, Deep-Sea Res., 34, 1733-1743, 1987.

Dickson, A. G., Sabine, C. L., and Christian, J. R.: Guide to best practices for ocean $\mathrm{CO}_{2}$ measurements, PICES Special Publication 3, IOCCP report No. 8, 191 pp., 2007.

Egge, J. K., Thingstad, T. F., Larsen, A., Engel, A., Wohlers, J., Bellerby, R. G. J., and Riebesell, U.: Primary production during nutrient-induced blooms at elevated $\mathrm{CO}_{2}$ concentrations, Biogeosciences, 6, 877-885, doi:10.5194/bg-6-877-2009, 2009.

Eggers, S. L., Lewandowska, A. M., and Barcelos e Ramos, J.: Blanco-Ameijeiras, S., Gallo, and Matthiessen, B.: Community composition has greater impact on the functioning of marine phytoplankton communities than ocean acidification, Global Change Biol., 20, 713-723, 2014.

Egleston, E. S., Sabine, C. L., and Morel, F. M. M.: Revelle revisited: buffer factors that quantify the response of ocean chemistry to changes in DIC and alkalinity, Global Biogeochem. Cy., 24, GB1002, doi:10.1029/2008GB003407, 2010.

Engel, A., Zondervan, I., Aerts, K., Beaufort, L., Benthien, A., Chou, L., Delille, B., Gattuso, J.-P., Harlay, J., Heemann, C., Hoffmann, L., Jacquet, S., Nejstgaard, J., Pizay, M. D., RochelleNewall, E., Schneider, U., Terbrueggen, A., and Riebesell, U.: Testing the direct effect of $\mathrm{CO}_{2}$ concentration on a bloom of the coccolithophorid Emiliania huxleyi in mesocosm experiments, Limnol. Oceanogr., 50, 493-507, 2005.

Engel, A., Borchard, C., Piontek, J., Schulz, K. G., Riebesell, U., and Bellerby, R.: $\mathrm{CO}_{2}$ increase ${ }^{14} \mathrm{C}$ primary production in an Arctic plankton community, Biogeosciences, 10, 1291-1308, doi:10.5194/bg-10-1291-2013, 2013.

Feng, Y., Hare, C. E., Leblanc, K., DiTullio, G. R., Lee, P. A., Wilhelm, S. W., Sun, J., Rose, J. M., Nemcek, N., Benner, I., and Hutchins, D. A.: The effects of increased $p \mathrm{CO}_{2}$ and temperature on the North Atlantic Spring Bloom: I. The phytoplankton community and biogeochemical response, Mar. Ecol.-Prog. Ser., 388, 13-25, 2009.

Flynn, K. J., Blackford, J. C., Baird, M. E., Raven, J. A., Clark, D. R., Beardall, J., Brownlee, C., Fabian, H., and Wheeler, G. L.: Changes in $\mathrm{pH}$ at the exterior surface of plankton with ocean acidification, Nat. Clim. Change, 2, 510-513, 2012. 
Gattuso, J.-P. and Hansson, L.: Ocean acidification: background and history, in: Ocean Acidification, Oxford, edited by: Gattuso, J.-P. and Hansson, L., Oxford University Press, Oxford, 1-20, 2011.

Gattuso, J.-P., Gao, K., Lee, K., Rost, B., and Schulz, K. G.: Approaches and tools to manipulate the carbonate chemistry, in: Riebesell, U., Fabry, V. J., Hansson, L., and Gattuso, J. P.: Guide to Best Practices for Ocean Acidification Research and Data Reporting, Publications Office of the European Union, Luxembourg, 263 pp., 2010.

Giordano, M., Beardall, J., and Raven, J. A.: $\mathrm{CO}_{2}$ concentrating mechanisms in algae: Mechanisms, environmental modulation, and evolution, Annu. Rev. Plant. Biol., 56, 99-131, 2005.

Hare, C. E., Leblanc, K., DiTullio, G. R., Kudela, R. M., Zhang, Y., Lee, P. A., Riseman, S., and Hutchins, D. A.: Consequences of increased temperature and $\mathrm{CO}_{2}$ for phytoplankton community structure in the Bering Sea, Mar. Ecol.-Prog. Ser., 352, 9-16, 2007.

Havenhand, J., Dupont, S., and Quinn, G. P.: Designing ocean acidification experiments to maximise interference, in: Riebesell, U., Fabry, V. J., Hansson, L., and Gattuso, J. P.: Guide to Best Practices for Ocean Acidification Research and Data Reporting, Publications Office of the European Union, Luxembourg, 263 pp., 2010.

Hilton, J., Lishman, J. P., Mackness, S., and Heaney, S. I.: An automated method for the analysis of particulate carbon and nitrogen in natural waters, Hydrobiologica, 141, 269-271, 1986.

Hofmann, G. E., Barry, J. P., Edmunds, P. J., Gates, R. D., Hutchins, D. A., Klinger, T., and Sewell, M. A.: The effect of Ocean acidification on calcifying organism in marine ecosystems: an organism-to-ecosystem perspective, Annu. Rev. Ecol. Evol. S., 41, 127-147, 2010.

Hopkins, F. E., Turner, S. M., Nightingale, P. D., Steinke, M., Bakker, D., and Liss, P. S.: Ocean acidification and marine gas emissions, P. Natl. Acad. Sci. USA, 107, 760-765, 2010

Hopkins, F. E. and Archer, S. D.: Consistent increase in dimethyl sulphide (DMS) in response to high $\mathrm{CO}_{2}$ in five shipboard bioassays from contrasting NW European waters, Biogeosciences Discuss., 11, 2267-2303, doi:10.5194/bgd-11-2267-2014, 2014.

Hopkinson, B. A., Xu, Y., Shi, D., McGinn, P. J., and Morel, F. M. M.: The effect of $\mathrm{CO}_{2}$ on the photosynthetic physiology of phytoplankton in the Gulf of Alaska, Limnol. Oceanogr., 55, 20112024, 2010.

Hoppe, C. J. M. Hassler, C. S. Payne, C. D., Tortell, P. D., Rost, B., and Trimborn, S.: Iron limitation modulates ocean acidification effects on Southern Ocean phytoplankton communities, PLoS ONE., 8, e79890, doi:10.1371/journal.pone.007989, 2013.

Jin, P., Gao, K., and Beardall, J.: Evolutionary responses of a Coccolithophorid Gephyrocapsa oceanica to ocean acidification, Evolution, 67, 1869-1878, 2013.

Joint, I., Doney, S. C., and Karl, D. M.: Will ocean acidification affect marine microbes?, ISME J., 5, 1-7, 2011.

Kirkwood, D. S.: Nutrients: a practical note on their determination in seawater, Techniques in marine environmental science no. 17 , ICES, Copenhagen, Denmark, 1996.

Kolber, Z. S., Prasil, O., and Falkowski, P. G.: Measurements of variable chlorophyll fluorescence using fast repetition rate techniques: defining methodology and experimental protocols, BBABioenergetics, 1367, 88-106, 1998.
Krause, E., Wichels, A., Giminez, L., Lunau, M., Schilhabel, M. B., and Gerdts, G.: Small Changes in $\mathrm{pH}$ have direct effects on Marine bacterial community composition: a microbial approach, PLoS ONE, 7, e47035, doi:10.1371/journal.pone.0047035, 2012.

Kuhn, S. F. and Raven, J. A.: Photosynthetic oscillation in individual cells of the marine diatom Coscinodiscus wailesii (Bacillariophyceae) revealed by microsensor measurements, Photosynth. Res., 95, 37-44, 2008.

LaRoche, J., Rost, B., and Enjel, A.: Bioassays, batch culture and chemostat experimentation, in: Riebesell, U., Fabry, V. J., Hansson, L., and Gattuso, J. P.: Guide to Best Practices for Ocean Acidification Research and Data Reporting, Publications Office of the European Union, Luxembourg, 263 pp., 2010.

Lewis, E. and Wallace, D. W. R.: Program developed for $\mathrm{CO}_{2}$ system calculations. ORNL/CDIAC-105. Carbon Dioxide Information Analysis Center, Oak Ridge National Laboratory, US Department of Energy, Oak Ridge, Tennessee, 1998.

Liu, J., Weinbauer, M. G., Maier, C., Dai, M., and Gattuso, J.-P.: Effect of ocean acidification on microbial diversity and on microbedriven biogeochemistry and ecosystem functioning, Aquat. Microb. Ecol., 61, 291-305, doi:10.3354/ame01446, 2010.

Lohbeck, K. T., Riebesell, U., and Reusch, T. B. H.: Adaptative evolution of a key phytoplankton species to ocean acidification, Nat. Geosci., 5, 346-351, doi:10.1038/NGEO1441, 2012.

Lomas, M. W., Hopkinson, B. M., Losh, J. L., Ryan, D. E., Shi, D. L., Xu, Y., and Morel, F. M. M.: Effect of ocean acidification on cyanobacteria in the subtropical North Atlantic, Aquat. Microb. Ecol., 66, 211-222, 2012.

Losh, J. L., Morel, F. M. M., and Hopkinson, B. M.: Modest increase in the $\mathrm{C}: \mathrm{N}$ ratio of $\mathrm{N}$-limited phytoplankton in the California Current in response to high $\mathrm{CO}_{2}$, Mar. Ecol.-Prog. Ser., 468, 31-42, 2012.

MacGilchrist, G. A., Shi, T., Tyrrell, T., Richier, S., Moore, C. M., Dumousseaud, C., and Achterberg, E. P.: Effect of enhanced $p \mathrm{CO}_{2}$ levels on the production of dissolved organic carbon and transparent exopolymer particles in short-term bioassay experiments, Biogeosciences, 11, 3695-3706, doi:10.5194/bg-113695-2014, 2014.

Marie, D., Partensky, F., Jacquet, S., and Vaulot, D.: Enumeration and cell cycle analysis of natural populations of marine picoplankton by flow cytometry using the nucleic acid stain SYBR Green I, Appl. Environ. Microbiol., 63, 186-93, 1997.

Mehrbach, C., Culberson, C. H., Hawley, J. H., and Pytkowicz, R. M.: Measurement of the apparent dissociation constants of carbonic acid in seawater at atmospheric pressure, Limnol. Oceanogr., 18, 897-907, 1973.

Milligan, A. J.: Plankton in an acidified ocean, Nature Climate Change, 2, 489-490, 2012.

Moore, C. M., Suggett, D. J., Hickman, A. E., Kim, Y.-N., Tweddle, J. F., Sharples, J., Geider, R. J., and Holligan, P. M.: Phytoplankton photoacclimatation and photoadaptation in response to environmental gradients in a shelf sea, Limnol. Oceanogr., 51, 936-949, 2006.

Orr, J. C., Fabry, V. J., Aumont, O., Bopp, L., Doney, S. C., Feely, R. A., Gnanadesikan, A., Gruber, N., Ishida, A., Joos, F., Key, R. M., Lindsay, K., Maier-Reimer, E., Matear, R., Monfray, P., Mouchet, A., Najjar, R. G., Plattner, G. K., Rodgers, K. B., Sabine, C. L., Sarmiento, J. L., Schlitzer, R., Slater, R. D., Tot- 
terdell, I. J., Weirig, M. F., Yamanaka, Y., and Yool, A.: Anthropogenic ocean acidification over the twenty-first century and its impact on calcifying organisms, Nature, 437, 681-686, 2005.

Passow, U. and Alldredge, A.: A dye-binding assay for the spectrophotometric measurement of transparent exopolymer particles (TEP), Limnol. Oceanogr., 40, 1326-1335, 1995.

Patsch, J. and Lorkowski, I.: Comparison of two techniques to separate physical-and biological- mediated $p \mathrm{CO}_{2}$ in seawater, Limnol. Oceanogr.-Meth., 11, 41-52, 2013.

Pierrot, D., Lewis, E., and Wallace, D. W. R.: MS Excel Program Developed for CO2 System Calculations, ORNL/CDIAC-105. Carbon Dioxide Information Analysis Center, Oak Ridge National Laboratory, US Department of Energy, Oak Ridge, Tennessee, 2006.

Poulton, A. J., Sanders, R., Holligan, P. M., Stinchcombe, M. C., Adey, T. R., Brown, L., and Chamberlain, K.: Phytoplankton mineralisation in the tropical and subtropical Atlantic Ocean, Global Biogeochem. Cy., 20, GB4002, doi:10.1029/2006GB002712, 2006.

Poulton, A. J., Charalampopouolou, A., Young, J. R., Tarran, G. A., Lucas, M. I., and Quartly, G. D.: Coccolithophore dynamics in non-bloom conditions during late summer in the central Iceland Basin (July-August 2007), Limnol. Oceanogr., 55, 1601-1613, 2010.

Poulton, A. J., Stinchcombe, M. C., Achterberg, E. P., Bakker, D. C. E., Dumousseaud, C., Lawson, H. E., Lee, G. A., Richier, S., Suggett, D. J., and Young, J. R.: Coccolithophores on the northwest European shelf: calcification rates and environmental controls, Biogeosciences, 11, 3919-3940, doi:10.5194/bg-11-39192014, 2014

Raimbault, P., Diaz, F., Pouvesle, W., and Boudjellal, B.: Simultaneous determination of particulate organic carbon, nitrogen and phosphorus collected on filters, using a semi-automatic wetoxidation method., Mar. Ecol. Prog. Ser, 180, 289-295, 1999.

Raven, J. A.: Exogenous inorganic carbon sources in plant photosynthesis, Biol. Rev. Camb. Philos. Soc., 45, 167 pp., 1970.

Raven, J. A. and Johnston, A. M.: Mechanisms of inorganic carbon acquisition in marine phytoplankton, and their implications for the use of other resources, Limnol. Oceanogr., 36, 1701-1714, 1991.

Raven, J. A., Giordano, M., Beardall, J., and Maberly, S. C.: Algal and aquatic plant carbon concentrating mechanisms in relation to environmental change, Photosynth. Res., 109, 281-96, doi:10.1007/s11120-011-9632-6, 2011.

Rees, A. P., Brown, I., Clark, D. R., and Torres, R.: The Lagrangian progression of nitrous oxide within filaments formed in the Mauritanian upwelling, Geophys. Res. Lett., 38, L21606, doi:10.1029/2011GL049322, 2011.

Rerolle, V. M. C., Floquet, C. F. A., Mowlem, M. C., Connelly, D. P., Achterberg, E. P., and Bellerby, R. R. G. J.: Seawater-pH measurements for ocean-acidification observations, Trac-Trend. Anal. Chem., 40, 146-157, 2012.

Reusch, T. B. H and Boyd, P. W.: Experimental evolution meets marine phytoplankton, Evolution, 67, 1849-1859, 2013.

Richier, S., Achterberg E. P., Archer S., Bretherton L., Brown I., Clark D., Dumousseaud C., Holland R. J., Hopkins F. E., MacGilchrist G. A., Moore C. M., Poulton A., Rees A., Shi T., Stinchcombe M., Suggett D., Zubkov M. V., Young J., and Tyrrell T.: Ocean acidification impacts on Sea Surface biology and biogeochemistry in Northwest European Shelf Seas: a highreplicated shipboard approach. British Oceanographic Data Centre - Natural Environmental Research Council, UK, 2014.

Ridgwell, A., Schmidt, D. N., Turley, C., Brownlee, C., Maldonado, M. T., Tortell, P., and Young, J. R.: From laboratory manipulations to Earth system models: scaling calcification impacts of ocean acidification, Biogeosciences, 6, 2611-2623, doi:10.5194/bg-6-2611-2009, 2009.

Riebesell, U., Schulz, K. G., Bellerby, R. G. J., Botros, M., Fritsche, P., Meyerhöfer, M., Neill, C., Nondal, G., Oschlies, A., Wohlers, J., and Zollner, E.: Enhanced biological carbon consumption in a high $\mathrm{CO}_{2}$ ocean, Nature, 450, 545-548, 2007.

Riebesell, U., Kortzinger, A., and Oschlies, A.: Sensitivities of marine carbon fluxes to ocean change, P. Natl. Acad. Sci. USA, 106, 20602-20609, 2009.

Riebesell, U. and Tortell, P. D.: Effects of ocean acidification on pelagic organisms and ecosystems, in: Ocean Acidification, edited by: Gattuso, J.-P. and Hansson,L., Oxford University Press Inc., New York, 99-121, 2011.

Riebesell, U., Gattuso, J.-P., Thingstad, T. F., and Middelburg, J. J.: Preface "Arctic ocean acidification: pelagic ecosystem and biogeochemical responses during a mesocosm study", Biogeosciences, 10, 5619-5626, www.biogeosciences.net/10/5619/ 2013/, 2013.

Rose, J. M., Feng, Y., Gobler, C. J., Gutierrez, R., Hare, C. E., Leblanc, K., and Hutchins, D. A.: Effects of increased $p \mathrm{CO}_{2}$ and temperature on the North Atlantic spring bloom. II. Microzooplankton abundance and grazing, Mar. Ecol.-Prog. Ser., 388, 27 40, 2009.

Rost, B., Zondervan, I., and Wolf-Gladrow, D.: Sensitivity of phytoplankton to future changes in ocean carbonate chemistry: current knowledge, contradictions and research directions, Mar. Ecol. Prog. Ser., 373, 227-237, 2008

Royal Society: Ocean acidification due to increasing atmospheric carbon dioxide, 60, Policy Document 12/05, The Royal Society, London, 2005.

Sambrotto, R. N., Savidge, G., Robinson, C., Boyd, P., Takahashi, T., Karl, D. M., Langdon, C., Chipman, D., Marra, J., and Codispoti, L.: Elevated consumption of carbon relative to nitrogen in the surface ocean, Nature, 363, 248-250, 1993.

Schaum, E., Rost, B., Millar, A. J., and Collins, S.: Variation in plastic responses of a globally distributed picoplankton species to ocean acidification, Nat. Clim. Change, 3, 298-302, 2013.

Schulz, K. G., Bellerby, R. G. J., Brussaard, C. P. D., Büdenbender, J., Czerny, J., Engel, A., Fischer, M., Koch-Klavsen, S., Krug, S. A., Lischka, S., Ludwig, A., Meyerhöfer, M., Nondal, G., Silyakova, A., Stuhr, A., and Riebesell, U.: Temporal biomass dynamics of an Arctic plankton bloom in response to increasing levels of atmospheric carbon dioxide, Biogeosciences, 10, 161180, doi:10.5194/bg-10-161-2013, 2013.

Silyakova, A., Bellerby, R. G. J., Schulz, K. G., Czerny, J., Tanaka, T., Nondal, G., Riebesell, U., Engel, A., De Lange, T., and Ludvig, A.: Pelagic community production and carbon-nutrient stoichiometry under variable ocean acidification in an Arctic fjord, Biogeosciences, 10, 4847-4859, doi:10.5194/bg-10-4847-2013, 2013.

Smith, F. A. and Raven, J. A.: Intracellular $\mathrm{pH}$ and its regulation, Annu. Rev. Plant Physio., 30, 289-311, 1979. 
Spies, A.: Growth rates of Antartica marine phytoplankton in the Weddell sea, Mar. Ecol.-Prog. Ser., 41, 267-274, 1987.

Spyres, G., Nimmo, M., Worsfold, P. J. Achterberg, E. P., and Miller, A. E. J.: Determination of dissolved organic carbon (DOC) in seawater using high temperature catalytic oxidation techniques, Trac-Trend. Anal. Chem., 19, 498-506, 2000.

Stefels, J., Dacey, J. W. H., and Elzenga, J. T. M.: In vivo DMSP-biosynthesis measurements using stable isotope incorporation and proton transfer reaction-mass spectrometry., Limnol. Oceanogr, -Meth, 7, 595-611, 2009

Suggett, D. J., Moore, C. M., Hickman, A. E., and Geider, R. J.: Interpretation of Fast Repetition Rate (FRR) fluorescence: signatures of community structure versus physiological state, Mar. Ecol. -Prog. Ser., 376, 1-19, 2009.

Tortell, P. D., DiTullio, G. R., Sigman, D. M., and Morel F. M. M.: $\mathrm{CO}_{2}$ effects on taxonomic composition and nutrient utilization in an Equatorial Pacific phytoplankton assemblage, Mar. Ecol.Prog. Ser., 236, 37-43, 2002.

Upstill-Goddard, R. C., Rees, A. P., and Owens, N. J. P.: Simultaneous high-precision measurements of methane and nitrous oxide in water and seawater by single phase equilibration gas chromatography, Deep-Sea Res. Pt. I., 43, 1669-1682, 1996.

Verardo, D. J., Froelich, P. N., and McIntyre, A.: Determination of organic carbon and nitrogen in marine sediments using the Carlo Erba NA-1500 analyzer, Deep-Sea Res., 37, 157-165, 1990.
Welschmeyer, N. A.: Fluorometric analysis of chlorophyll $a$ in the presence of chlorophyll $\mathrm{b}$ and pheopigments, Limnol. Oceanogr., 39, 1985-1992, 1994.

Wernberg, T., Smale, D. A., and Thomsen, M. S.: A decade of climate change experiments on marine organisms: procedures, patterns and problems, Glob. Change Biol., 18, 1491-1498, 2012.

Wu, Y., Campbell, D. A., Irwin, A., Suggett, D. J., and Finkel, Z. V.: Ocean acidification enhances the growth rate of larger diatoms, Limnol. Oceanogr., 59, 1027-1034, 2014.

Yoshimura, T., Suzuki, K., Kiyosawa, H., Ono, T., Hattori, H., Kuma, K., and Nishioka, J.: Impacts of elevated $\mathrm{CO}_{2}$ on particulate and dissolved organic matter production: microcosm experiments using iron-deficient plankton communities in open subarctic waters, J. Oceanogr., 69, 601-618. 2013.

Young, J. R., Poulton, A. J., and Tyrrell, T.: Morphology of Emiliania huxleyi coccoliths on the North West European Shelf - is there an influence of carbonate chemistry?, Biogeosciences Discuss., 2014.

Zondervan, I.: The effects of light, macronutrients, trace metals and $\mathrm{CO}_{2}$ on the production of calcium carbonate and organic carbon in coccolithophores - a review, Deep-Sea Res. Pt. II., 54, 521537, 2007.

Zubkov, M. V., Holland, R. J., Burkill, P. H., Croudace, I. W., and Warwick, P. E.: Microbial abundance, activity and iron uptake in vicinity of the Crozet Isles in November 2004-January 2005, Deep-Sea Res. Pt. II., 54, 18-20, 2007. 